\title{
Autoradiographic Localization of Serotonin Receptor Subtypes in Cat Visual Cortex: Transient Regional, Laminar, and Columnar Distributions during Postnatal Development
}

\author{
Richard H. Dyck and Max S. Cynader \\ Department of Ophthalmology, University of British Columbia, 2550 Willow Street, Vancouver, British Columbia, Canada \\ V5Z 3N9
}

Postnatal changes in the distribution of 5-HT receptor subtypes in the visual cortex of cats were assessed both qualitatively and quantitatively using in vitro autoradiographic methods. The 5-HT $1 \mathrm{~A}, 1 \mathrm{C}, 2$, and 3 receptor subtypes and the 5-HT uptake $\left(5-\mathrm{HT}_{\mathrm{up}}\right)$ site were visualized with ${ }^{3} \mathrm{H}-8-\mathrm{hy}$ droxy-2(di- $n$-propyl-amino)tetralin, ${ }^{3} \mathrm{H}$-mesulergine, (2,5-dimethoxy-4-125/-iodophenyl)-2-aminopropane, ${ }^{3} \mathrm{H}-B R L 43694$, and ${ }^{3} \mathrm{H}$-cyanoimipramine, respectively. Although specific labeling of $5-\mathrm{HT}_{3}$ receptors was not detected in the cat visual cortex at any age, each of the remaining 5-HT receptor subtypes exhibited unique temporal, regional, and laminar patterns of expression in visual cortical areas 17, 18, and 19 and lateral suprasylvian cortex (LS). $5-\mathrm{HT}_{1 \mathrm{~A}}$ receptors were the earliest to demonstrate visual cortex-specific changes in expression. They exhibited peak levels of expression in all visual cortical areas, predominantly in supra- and infragranular layers, between postnatal day 10 (PD10) and PD30. Their levels in all areas declined progressively with increasing age. 5- $\mathrm{HT}_{1 \mathrm{C}}$ receptors demonstrated their highest levels of expression in the deeper half of layer IV, but only in area 17, between PD40 and PD75. The most striking feature of their distribution throughout this period was that, in layer IV and extending into layer III, the $5-\mathrm{HT}_{1 \mathrm{c}}$ receptors were concentrated in columns that were $400 \mu \mathrm{m}$ wide and had a center-to-center spacing of about $900 \mu \mathrm{m}$. This transient pattern of expression was not present beyond PD90. 5- $\mathrm{HT}_{2}$ receptors were most densely expressed in layer IV between PD40 and PD120, but they displayed a distinctly different distribution pattern. The densest binding of $5-\mathrm{HT}_{2}$ receptors was limited to the upper half of layer IV and found in areas 17, 18, and LS. The distribution of $5-\mathrm{HT}_{2}$ receptors along the dense band in layer IV of area 17 was discontinuous, exhibiting patches that were found in the same vertical columns as were the $5-\mathrm{HT}_{1 \mathrm{C}}$ receptors. Intermediate binding levels for the $\mathbf{5}-\mathrm{HT}_{2}$ receptors were found through layers I-III, the remainder of layer IV, and the subcortical white matter. The levels of 5-HT uptake sites increased gradually to reach adult levels by

Received Jan. 4, 1993; revised Apr. 2, 1993; accepted Apr. 15, 1993.

This work was submitted by R.H.D., in partial fulfillment of the requirements for the degree of Doctor of Philosophy, to the Program in Neuroscience at the University of British Columbia. This work was supported by MRC Program Grant PG29 to M.S.C. and an NSERC Fellowship to R.H.D.

Correspondence should be addressed to Richard Dyck at his present address: Department of Molecular Neurobiology, The Salk Institute, 10010 North Torrey Pines Road, La Jolla, CA 92037.

Copyright (C) 1993 Society for Neuroscience $0270-6474 / 93 / 134316-23 \$ 05.00 / 0$
PD40, but with a distribution pattern that was basically homogeneous, both across cortical regions and across laminae. The complementary spatial and temporal distributions of the different classes of 5-HT receptors suggest that each receptor subtype has distinctive actions during development and that serotonergic neurotransmission may play a critical role in determining the functional columnar organization of visual cortex.

[Key words: striate cortex, lateral suprasylvian cortex, area 17, area 18, area 19, postnatal development, 5-HT, ${ }_{1 A}, \mathrm{HT} \mathrm{T}_{1 C}$, 5-HT $, 5-\mathrm{HT}_{3}, 5-\mathrm{HT}$ transporter, columnar architecture, geniculocortical pathway]

The synaptic organization of the visual cortex of mammals is particularly susceptible to experience-dependent modifications of its functional organization during a distinct window of postnatal development. Although the intrinsic mechanisms underlying the formation and stabilization of synapses are not known, it is generally believed that the production of chemical messengers, at specific times during development, might influence the synaptic organization of visual cortex. Indeed, many neurotransmitter systems have been proposed to function in a unique capacity, during the development of the nervous system, in regulating neuronal differentiation, growth, and synaptic plasticity (for reviews, see Mattson, 1988; Lipton and Kater, 1989; Whitaker-Azmitia, 1991).

The role that neurotransmitter systems play in the development and plasticity of visual cortical connectivity has been the subject of intensive study for several decades. Noradrenergic (Kasamatsu et al., 1979), acetylcholinergic (Bear and Singer, 1986), and glutamatergic (Kleinschmidt et al., 1987; Fox et al., 1991) systems have all been proposed to be necessary for maintaining visual cortical plasticity in kittens during the critical period. Transient, region-specific increases in the distribution of neurotransmitter-specific afferents (Bear et al., 1985; Dyck et al., 1993a,b), and/or their receptors (Kasamatsu and Shirokawa, 1985; Bode-Greuel and Singer, 1989; Cynader et al., 1990; Prusky and Cynader, 1990) have been described to parallel the time course of the critical period and are thus effectively positioned to direct specific developmental processes (Cynader et al., 1990, 1991).

Recently, the potential involvement of serotonergic systems in neocortical development has been addressed using physiological and anatomical methods. Immunohistochemical and autoradiographic analyses have demonstrated a transient serotonergic hyperinnervation of the rat visual cortex, which is present 
Table 1. Summary of incubation parameters

\begin{tabular}{|c|c|c|c|c|c|}
\hline & \multicolumn{5}{|l|}{ Receptor subtype } \\
\hline & $5-\mathrm{HT}_{\mathrm{IA}}$ & $5-\mathrm{HT}_{1 \mathrm{C}}$ & $5-\mathrm{HT}_{2}$ & $5-\mathrm{HT}_{3}$ & $5-\mathrm{HT}_{\mathrm{up}}$ \\
\hline Radioligand & ${ }^{3} \mathrm{H}-8-\mathrm{OH}-\mathrm{DPAT}$ & ${ }^{3} \mathrm{H}$-mesulergine & ${ }^{125} \mathrm{I}-\mathrm{DOI}$ & ${ }^{3} \mathrm{H}-B R L 43694$ & ${ }^{3} \mathrm{H}-\mathrm{CN}-\mathrm{IMI}$ \\
\hline Concentration & $2.0 \mathrm{nM}$ & $4.5 \mathrm{nM}$ & $0.5 \mathrm{~nm}$ & $2.0 \mathrm{nM}$ & $0.3 \mathrm{nM}$ \\
\hline Cold displacer & $10 \mu \mathrm{M} 5-\mathrm{HT}$ & $10 \mu \mathrm{M} 5-\mathrm{HT}$ & $1 \mu \mathrm{M} \mathrm{DOB}^{a}$ & $10 \mu \mathrm{M} 5-\mathrm{HT}$ & $1 \mu \mathbf{M}$ citalopram \\
\hline Wash and incubation buffer & $\begin{array}{l}170 \mathrm{~mm} \text { Tris- } \mathrm{HCl} \\
(\mathrm{pH} 7.6), \\
4 \mathrm{mM} \mathrm{CaCl}_{2}, \\
10 \mu \mathrm{M} \text { pargylline, } \\
0.01 \% \text { ascorbate }\end{array}$ & $\begin{array}{l}170 \mathrm{~mm} \text { Tris-HCl } \\
(\mathrm{pH} 7.6) \\
2 \mu \mathrm{M} \text { spiperone, } \\
0.01 \% \text { ascorbate }\end{array}$ & $\begin{array}{l}50 \mathrm{~mm} \text { Tris- } \mathrm{HCl} \\
(\mathrm{pH} \mathrm{7.4)} \\
0.1 \% \mathrm{BSA} \\
0.01 \% \text { ascorbate }\end{array}$ & $\begin{array}{l}50 \text { mM HEPES } \\
(\mathrm{pH} \mathrm{7.4)}\end{array}$ & $\begin{array}{l}50 \mathrm{~mm} \text { Tris- } \mathrm{HCl} \\
(\mathrm{pH} 7.4) \\
5 \mathrm{mM} \mathrm{KCl}_{2} \\
120 \mathrm{~mm} \mathrm{NaCl}\end{array}$ \\
\hline Preincubation wash & $30 \mathrm{~min}$ & $30 \mathrm{~min}$ & $30 \mathrm{~min}$ & $15 \mathrm{~min}$ & $30 \mathrm{~min}$ \\
\hline Incubation time & $60 \mathrm{~min}$ & $120 \mathrm{~min}$ & $60 \mathrm{~min}$ & $60 \mathrm{~min}$ & $24 \mathrm{hr}$ \\
\hline Postincubation wash & $2 \times 5 \mathrm{~min}$ & $2 \times 10 \mathrm{~min}$ & $3 \times 10 \mathrm{~min}$ & $2 \times 3 \mathrm{~min}$ & $1 \mathrm{hr}$ \\
\hline Film exposure & 8 weeks & 10-12 weeks & $3 \mathrm{~d}$ & 6-8 months & 2 weeks \\
\hline
\end{tabular}

${ }^{a}$ DOB, 2,5-dimethoxy-4-bromoamphetamine.

only during early postnatal life (D'Amato ct al., 1987; BenncttClarke et al., 1991). The distribution of serotonergic terminals in the visual cortex of cats and ferrets also demonstrate agedependent, laminar-specific changes during postnatal development (Gu et al., 1990; Voigt and De Lima, 1991b). Moreover, the developmental plasticity of ocular dominance columns in kittens has been shown to be disrupted by chronic blockade of 5-HT receptors (Gu and Singer, 1991). Although the regional distribution of several 5-HT receptor subtypes has been studied in visual cortex of the adult rat (Pazos and Palacios, 1985; Pazos et al., 1985), human (Hoyer et al., 1986a,b; Pazos et al., 1987a,b), and nonhuman primate (Rakic et al., 1988; Lidow et al., 1989; Parkinson et al., 1989), surprisingly little is known about the distribution of the different receptors responsible for the transduction of the 5-HT signal during development.

The cellular actions of 5-HT in the CNS are mediated by specific, high-affinity receptors. In the last decade, the number of different 5-HT receptor subtypes has proliferated from two to at least seven members, belonging to three major families (for recent reviews, see Peroutka, 1990; Radja et al., 1991; Zifa and Fillion, 1992). The 5- $\mathrm{HT}_{1}$ and $5-\mathrm{HT}_{2}$ families belong to the G-protein-coupled receptor superfamily (Hartig, 1989) and were originally identified on the basis of their differential affinities for ${ }^{3} \mathrm{H}-5-\mathrm{HT}$ and ${ }^{3} \mathrm{H}$-spiperone (Peroutka and Snyder, 1979; Pedigo et al., 1981). The 5-HT and $5-\mathrm{HT}_{2}$ families are further subdivided into specific subtypes. The $5-\mathrm{HT}_{1}$ family consists of 5-HT ${ }_{1 \mathrm{~A}}, 5-\mathrm{HT}_{\mathrm{IB}}$ (Pedigo et al., 1981), 5-HT $\mathrm{HD}_{\mathrm{D}}$ (Heuring and Peroutka, 1987), and 5-HT ${ }_{1 \mathrm{E}}$ (Leonhardt et al., 1989) receptor subtypes. The $5-\mathrm{HT}_{1 \mathrm{~B}}$ and $5-\mathrm{HT}_{\mathrm{ID}}$ subtypes are considered to be homologous receptors in different species (Heuring and Peroutka, 1987). The 5-HT IC receptor subtype (Pazos et al., 1984b; Yagaloff and Hartig, 1985), initially classified as a 5-HT, receptor, is now considered to belong together with the classical $5-\mathrm{HT}_{2}$ receptor subtype based on their similar molecular struc- ture, second-messenger coupling, and pharmacological properties (Hoyer, 1988; Sanders-Bush, 1988; Hartig, 1989) as members of the $5-\mathrm{HT}_{2}$ family. The last major family of 5-HT receptors, called $5-\mathrm{HT}_{3}$, belongs to the ligand-gated ion channel superfamily (Kilpatrick et al., 1987; Derkach et al., 1989), and preliminary reports indicate that multiple subtypes may exist (Richardson and Engel, 1986), but their characterization has not yet been detailed.

In the present study we report the results of an autoradiographic study in cats that compares the ontogenetic distributions of 5-HT $\mathrm{HA}_{1 \mathrm{~A}}, 5-\mathrm{HT}_{1 \mathrm{C}}, 5-\mathrm{HT}_{2}$, and $5-\mathrm{HT}_{3}$ receptors as well as the high-affinity 5 -HT uptake site in visual cortical areas 17, 18, 19 , and lateral suprasylvian cortex (LS). The unavailability of specific ligands and radioligands for $5-\mathrm{HT}_{1 \mathrm{~B} / \mathrm{D}}$ and $5-\mathrm{HT}_{1 \mathrm{E}}$ sites precluded an autoradiographic evaluation of their distribution at this time. The temporal and regional expression patterns of the 5-HT receptor subtypes that we did examine strongly indicate that 5-HT receptors are effectively positioned to mediate important functional processes at critical stages of visual cortical development.

Preliminary results have been presented in abstract form (Dyck and Cynader, 1990a,b).

\section{Materials and Methods}

Animals. The normal distribution of 5-HT receptors was assessed in 24 cats at 10 ages between postnatal day 0 (PD0, day of birth) and adulthood ( $>$ PD360). At least two animals were used at every age described in the results, along with four adults and eight kittens studied at PD50. The cats were anesthetized with an overdose of sodium pentobarbital and perfused through the ascending aorta with $50-200 \mathrm{ml}$ of $0.1 \mathrm{M}$ phosphate buffer ( $\mathrm{pH} 7.4$ ) containing $0.9 \% \mathrm{NaCl}$. The brain was immediately removed, frozen in isopentane at $-50^{\circ} \mathrm{C}$, and then stored at $-30^{\circ} \mathrm{C}$ prior to sectioning. In two PD50 animals, the visual cortex from one hemisphere was opened and flattened, prior to freezing, to assess the overall distribution of 5-HT receptors in the tangential plane. The other hemisphere was cut in the parasagittal plane. Serial sections were

Figure 1. Autoradiographic images demonstrating the total binding of ${ }^{3} \mathrm{H}-8-\mathrm{OH}-\mathrm{DPAT}(A-I),{ }^{3} \mathrm{H}-\mathrm{mesulergine}\left(A^{\prime}-I^{\prime}\right)$, and ${ }^{125} \mathrm{I}-\mathrm{DOI}\left(A^{\prime \prime}-I^{\prime \prime}\right)$ to $5-\mathrm{HT}_{1 \mathrm{~A}}, 5-\mathrm{HT}_{\mathrm{IC}}$, and $5-\mathrm{HT}_{2}$ receptors, respectively, in near-adjacent sections through visual cortical areas 17, 18, 19, and lateral suprasylvian cortex $(L S)$ during postnatal development (age, in postnatal days, is indicated to left of each row). All the sections for each ligand were processed simultaneously, apposed to the same film, and photographed under identical conditions. Regional and temporal changes in density thus reflect actual changes in level of binding for each radioligand. Regional boundaries are indicated by broken lines in the left-hand panels. 
PDO

PD10

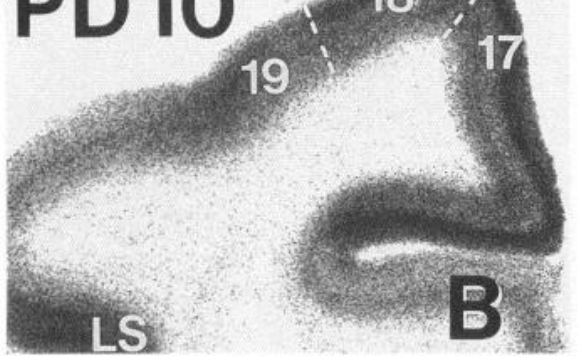

PD20

LS

\section{PD 30}
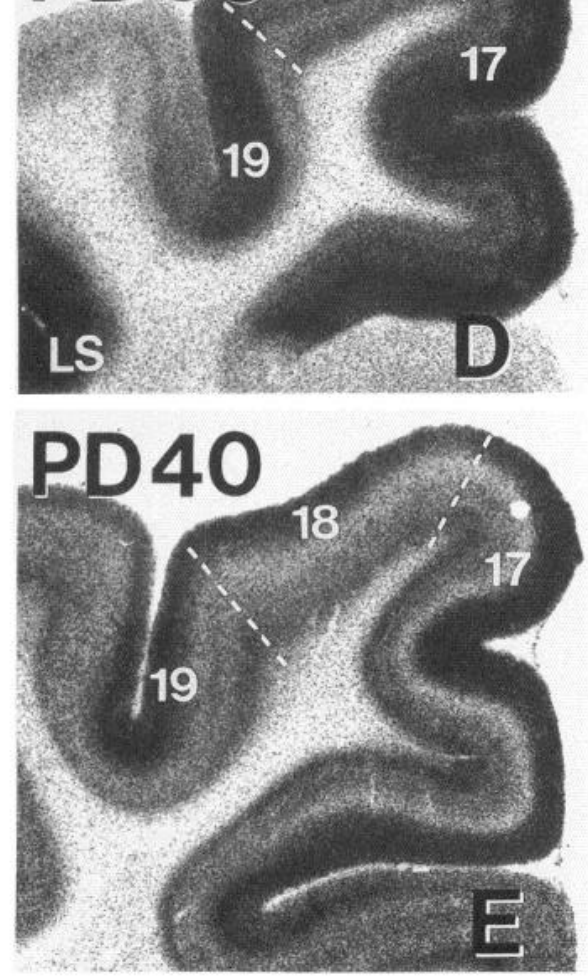
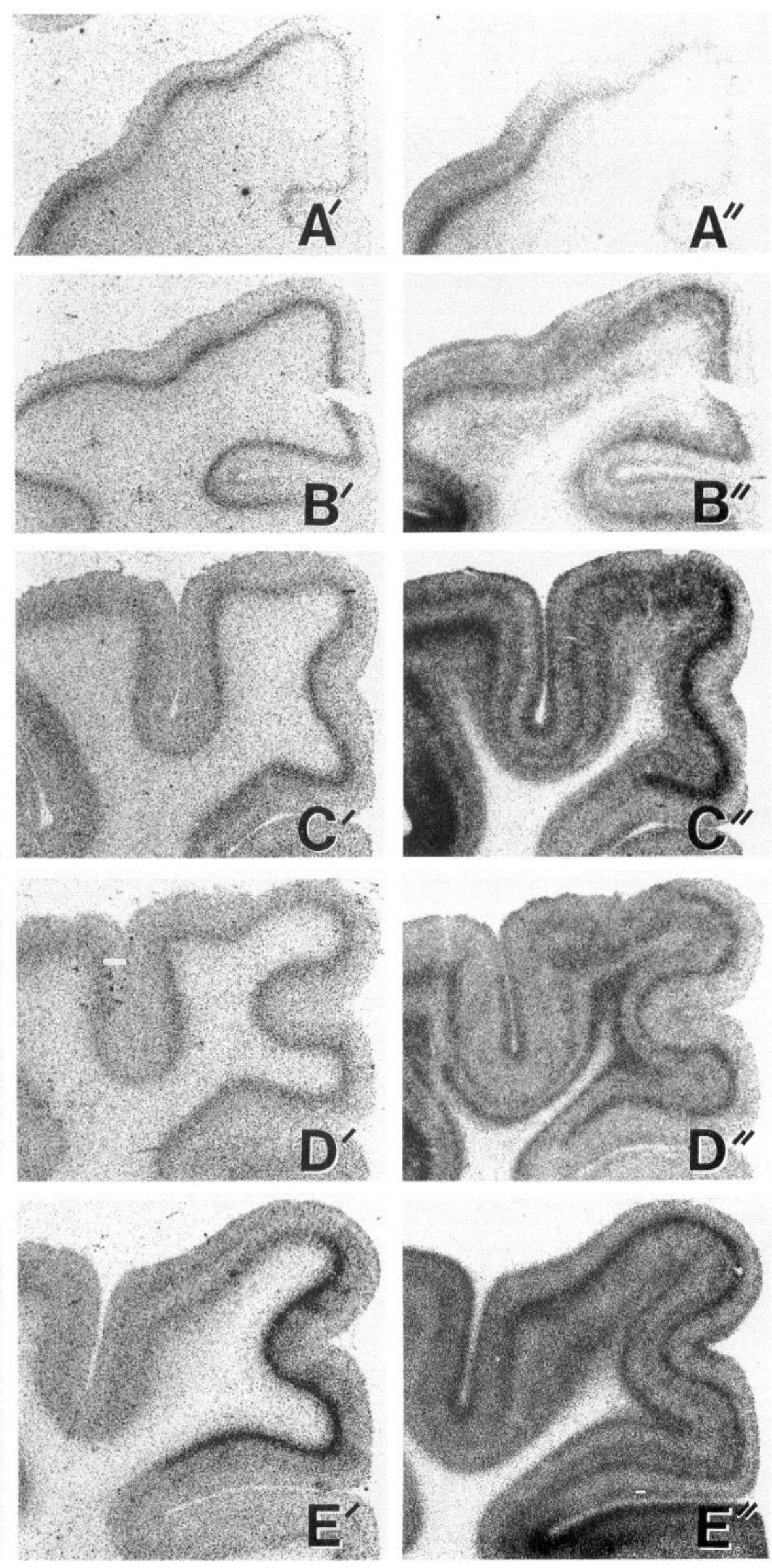

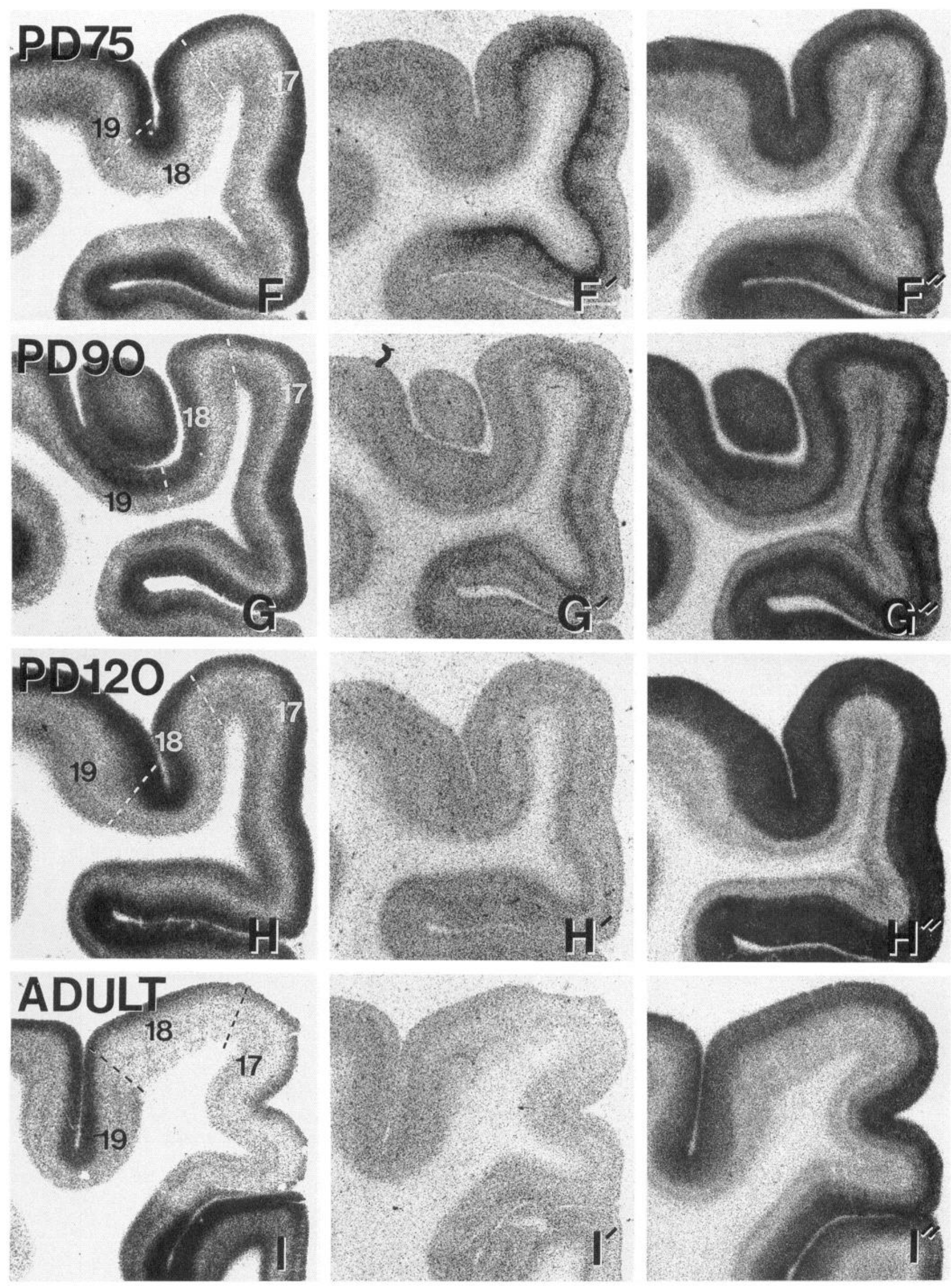
cut on a cryostat at $-20^{\circ} \mathrm{C}$ at a thickness of $20 \mu \mathrm{m}$, thaw mounted onto gelatin-coated glass slides, and stored at $-20^{\circ} \mathrm{C}$ for not longer than 4 weeks before processing for autoradiography.

Auloradiography. At each age $5-\mathrm{HT}_{1 \mathrm{~A}}, 5-\mathrm{HT}_{1 \mathrm{C}}$, and $5-\mathrm{HT}_{2}$ receptors and the 5-HT uptake site $\left(5-\mathrm{HT}_{\mathrm{Up}}\right)$ were labeled in near adjacent sections using ${ }^{3} \mathrm{H}-8$-hydroxy-2(di- $n$-propyl-amino)tetralin $\left[{ }^{3} \mathrm{H}-8-\mathrm{OH}-\mathrm{DPAT}\right.$; $169.9 \mathrm{Ci} / \mathrm{mmol}$; New England Nuclear (NEN)], ${ }^{3} \mathrm{H}-m e s u l e r g i n e ~(78 \mathrm{Ci} /$ mmol; Amersham), ( \pm )-1-(2,5-dimethoxy-4-1251-iodophenyl)-2-aminopropane ( ${ }^{125} \mathrm{I}-\mathrm{DOI} ; 2200 \mathrm{Ci} / \mathrm{mmol}$; NEN), and ${ }^{3} \mathrm{H}$-cyanoimipramine ( ${ }^{3} \mathrm{H}-\mathrm{CN}-\mathrm{IMI} ; 83.6 \mathrm{Ci} / \mathrm{mmol}$; NEN). In preliminary studies we also assessed the utility of ${ }^{3} \mathrm{H}$-2,5-dimethoxy-4-bromoamphetamine ( ${ }^{3} \mathrm{H}-\mathrm{DOB}$; NEN) to label 5- $\mathrm{HT}_{2}$ receptors, and ${ }^{3} \mathrm{H}$-citalopram (NEN) to label $5-\mathrm{HT}_{\text {Up }}$. Although all ligands demonstrated similar regional and temporal patterns of expression, ${ }^{125} \mathrm{I}-\mathrm{DOI}$ and ${ }^{3} \mathrm{H}-\mathrm{CN}$-IMI proved superior, in terms of specificity and specific activity, in labeling 5-HT ${ }_{2}$ receptors and 5-HT $\mathrm{Up}_{\mathrm{p}}$, respectively, and the results presented in this study are based on the binding of these ligands. We also used ${ }^{3} \mathrm{H}-\mathrm{BRL} 43694,{ }^{3} \mathrm{H}-\mathrm{GR} 65630$, or ${ }^{3} \mathrm{H}$-quipazine in binding studies to assess the distribution of $5-\mathrm{HT}_{3}$ receptors during visual cortical development.

The binding procedures we used and the specificity of each radioligand for individual 5-HT receptor subtypes are based on ligand characterizations that have been described previously in rat (Pazos and Palacios, 1985; Pazos et al., 1985; Titeler et al., 1985, 1987; Kilpatrick et al., 1987, 1988; Kovachich et al., 1988; McKenna et al., 1989; Nelson and Thomas, 1989), primate (Lidow et al., 1989; Parkinson et al., 1989), and human brain (Hoyer et al., 1986a,b; Pazos et al., 1987a,b). Any deviations from the published protocols are indicated by the specific incubation parameters used (buffers, incubation times, and ligand concentrations), outlined in Tablc 1, and briefly described here. The frozen sections were thawed, washed for $30 \mathrm{~min}$ in buffer, and then incubated, in the dark, in buffer containing the appropriate radioligand. Nonspecific binding was assessed in near-adjacent sections by including an excess of nonlabeled displacer in the incubation solution. Following incubation, sections were washed in buffer to remove unbound radioligand, briefly dipped in ice-cold distilled water, dried under a stream of cool air, and then exposed against Hyperfilm- $-{ }^{3} \mathrm{H}$ along with either ${ }^{3} \mathrm{H}$ or ${ }^{125} \mathrm{I}$ standards (Amersham). After developing the Hyperfilm, selected sections were stained with cresyl violet to facilitate the identification of cytoarchitectonic areas and cortical layers in relation to radioligand binding patterns.

Ouantitative densitometry. Auotradiographic images were captured digitally using a Macintosh IIfx-based image analysis system (Cohu 4915 CCD camera, Data Translation DT-2255 quick capture board) running IMAGE software (NIH, version 1.45). This software allowed radioligand binding to be measured in calibrated units of isotope concentration ( $\mathrm{nCi} / \mathrm{mg}$ tissue), within individual cortical layers. Nissl-stained sections were digitally superimposed upon autoradiographic images that allowed individual regions and cortical layers to be identified and measured densitometrically. The generation of densitometric profile plots using IMAGE, and the ability to align and superimpose digital images with ADOBE PHOTOSHOP (version 2.0), facilitated precise comparisons of the relative laminar and columnar distributions of the different 5-HT receptors in near-adjacent sections.

In the youngest animals (PD0), density measurements were obtained from $100-\mu \mathrm{m}$-wide regions, drawn within, and corresponding to, layers I, IV, V, and VI as well as superficial and deep cortical plate (CP), and white matter from areas $17,18,19$, and lateral suprasylvian cortex (LS). In animals older than PD0, the average density of $200-\mu \mathrm{m}$-wide regions drawn from layers I, II, III, superficial IV, deep IV together with superficial $V, I V$, and $W m$ was measured in each region. In all cases, four sections from each brain were used for the determination of specific ligand binding. Specific binding within an individual lamina or region was obtained by subtracting nonspecific binding, measured in nearadjacent sections incubated with unlabeled displacer, from the total bound radioligand measured in each of the four sections.

Several approaches were utilized to relate the pattern ofligand binding to laminar and regional borders. Selected sections were counterstained with cresyl violet and were then used to establish laminar borders in the various visual cortical areas based on cytoarchitectonic criteria established by Otsuka and Hassler (1962) in adult cats and Shatz and Luskin (1986) for early postnatal development. Some sections wcrc histochemically stained for cytochrome oxidase to demarcate layer IV within areas 17 and 18 (Wong-Riley, 1979). The borders of visual cortical areas were also determined according to the electrophysiologically defined maps of Tusa et al. $(1978,1979,1980,1981)$, which describe the relationships of regional borders and gyral patterns. Additional information was derived from comparisons to previous studies using autoradiographic markers having laminar specificity in area $17 / 18$ of developing cat visual cortex (Shaw et al., 1984, 1986; Prusky et al., 1987).

\section{Results}

The photographs in Figure 1 illustrate the changing distributions of 5-HT $\mathrm{HA}_{1 \mathrm{~A}}(A-I), 5-\mathrm{HT}_{1 \mathrm{C}}\left(A^{\prime}-I^{\prime}\right)$, and 5-HT $\left(A^{\prime \prime}-I^{\prime \prime}\right)$ receptors in near-adjacent sections through visual cortical areas 17,18 , and 19 between birth and adulthood. Autoradiographic images showing the binding to these receptors in LS during development are shown in Figure 2. Presented in Figure 3 are photographs of representative sections that illustrate the binding of ${ }^{3} \mathrm{H}-\mathrm{CN}-\mathrm{IMI}$ to $5-\mathrm{HT}_{\text {Up }}$ sites in PD20 $(A), \operatorname{PD} 75(B)$, and adult cat visual cortex $(C)$. All sections for each ligand were processed simultaneously and exposed against the same sheet of film, and were photographed and printed under identical conditions. Within these figures, the observable changes in density across different regions and laminae reflect real changes in total bound radioligand.

Regardless of the radioligand used, and even with 6 months of film exposure, we were unable to detect specific binding to $5-\mathrm{HT}_{3}$ receptors in the visual cortex at any age. However, very high concentrations of $5-\mathrm{HT}_{3}$ receptors (best labeled using ${ }^{3} \mathrm{H}$ BRL43694) were found in sections through the striatum and hippocampal formation of the same brains, indicating that this $5-\mathrm{HT}$ receptor subtype is not likely to be found in the visual cortex at detectable levels. The observation that the density of $5-\mathrm{HT}_{3}$ receptor binding sites is significantly less than that of any other 5-HT receptor class has been previously reported, and the authors also indicate that the utility of tritiated radioligands to visualize $5-\mathrm{HT}_{3}$ sites in the brain would be limited (Radja et al., 1991).

The photographic images generated from the autoradiograms represent the total binding (specific + nonspecific) of each radioligand. In the quantitative analyses described below, specific binding was assessed densitometrically by subtracting nonspecific (ns) from total binding. Across all ages used in this study, specific binding accounted for greater than $88.6 \%$ of total binding of ${ }^{3} \mathrm{H}-8$-OH-DPAT $(8.2 \%<\mathrm{ns}<11.4 \%)$, $>75.5 \%$ of binding of ${ }^{3} \mathrm{H}$-mesulergine $(11.1 \%<\mathrm{ns}<24.5 \%),>88.0 \%$ binding of ${ }^{125}$ I-DOI $(8.9 \%<\mathrm{ns}<12.6 \%)$, and $>84.0 \%$ of ${ }^{3} \mathrm{H}-\mathrm{CN}$-IMI $(8.6 \%<\mathrm{ns}<16.0 \%)$. In the following sections, the binding data are presented in units of $\mathrm{fmol} / \mathrm{mg}$ (wet weight) \pm SEM.

It is apparent from the autoradiograms in Figures 1-3 that the specific expression of each 5-HT receptor subtype is manifested by complex temporal, regional, and laminar patterns. In order to appreciate this complexity more fully, the autoradiographic data are broken down in the following sections beginning with general temporal, regional, and laminar analyses and ending with an examination of specific laminar and intralaminar distributions.

\section{Temporal patterns of expression}

Figure 4 demonstrates the effect of age on the binding of ${ }^{3} \mathrm{H}-8$ OH-DPAT, ${ }^{3} \mathrm{H}$-mesulergine, ${ }^{125} \mathrm{I}-\mathrm{DOI}$, and ${ }^{3} \mathrm{H}-\mathrm{CN}-\mathrm{IMI}$ to $5-\mathrm{HT}_{1 \mathrm{~A}}, 5-\mathrm{HT}_{1 \mathrm{C}}$, and $5-\mathrm{HT}_{2}$ receptors and $5-\mathrm{HT}_{\mathrm{Up}}$ sites, respectively, in postnatal cat visual cortex. These data represent the binding density of each receptor subtype averaged across areas $17,18,19$, and LS collectively, and are plotted as a proportion of peak binding. In general, all receptor subtypes exhibited their lowest levels of expression at birth, increased with 

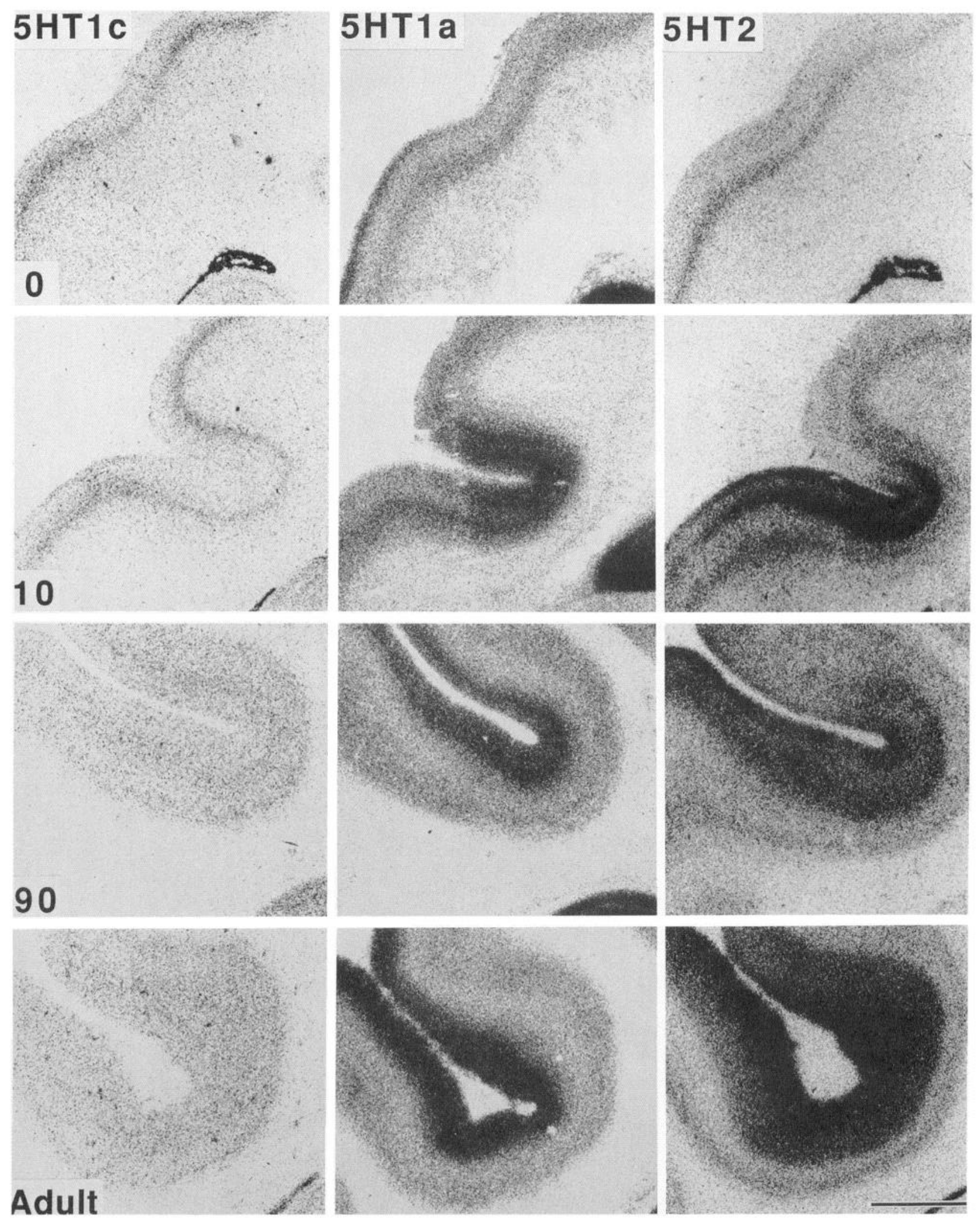

Figure 2. Autoradiographic images demonstrating differential binding patterns of ${ }^{3} \mathrm{H}-8$-OH-DPAT, ${ }^{3} \mathrm{H}-m e s u l e r g i n e$, and ${ }^{125} \mathrm{I}-\mathrm{DOI}$ to 5 -HT ${ }_{1 \mathrm{~A}}$,

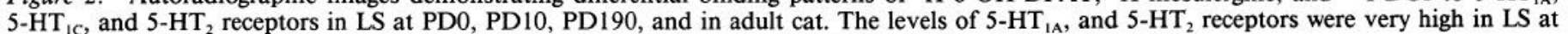
ages beyond PD10, but 5-HT ${ }_{1 \mathrm{C}}$ receptors were present only at very low abundance at all ages. Scale bar, $2 \mathrm{~mm}$. 

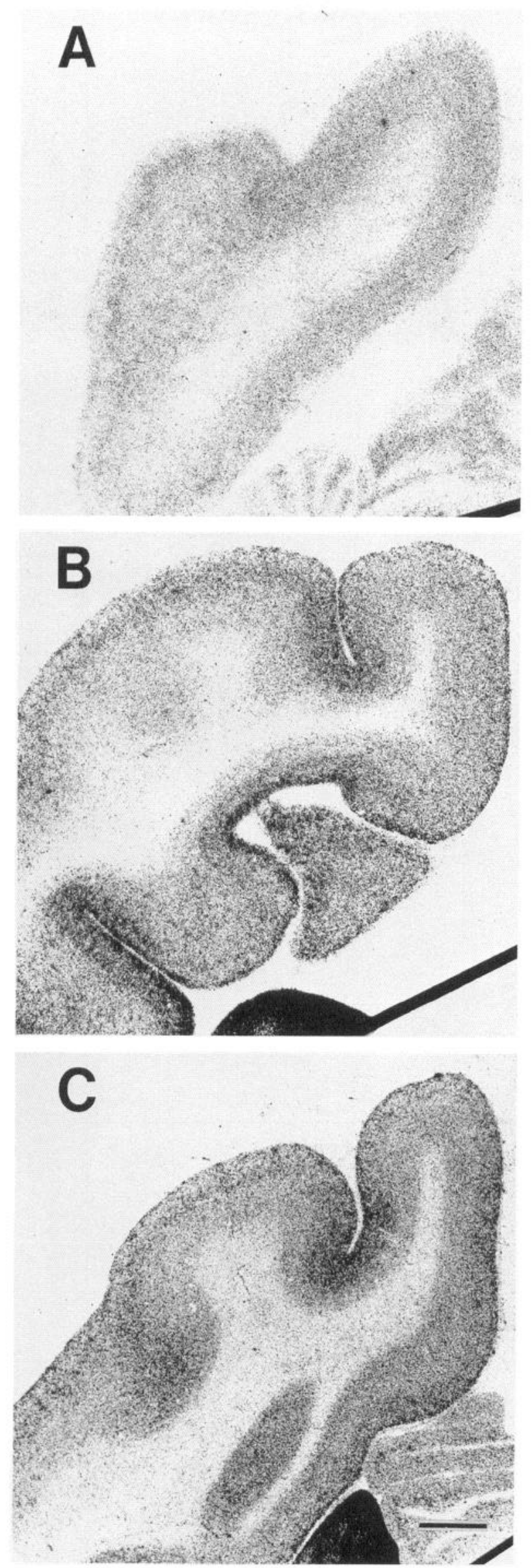

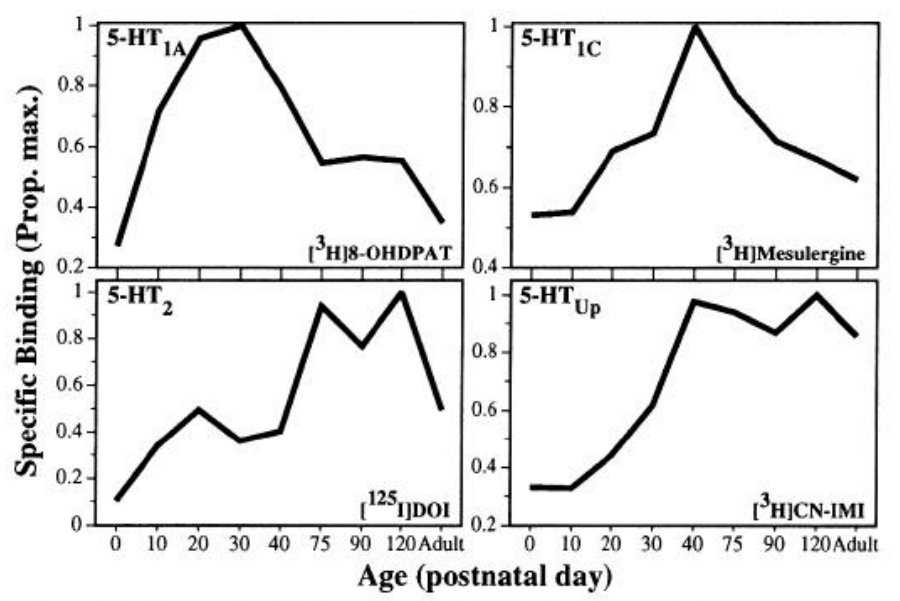

Figure 4. Age-related changes in the binding of ${ }^{3} \mathrm{H}-8-\mathrm{OH}-\mathrm{DPAT},{ }^{3} \mathrm{H}-$ mesulergine, ${ }^{125} \mathrm{I}-\mathrm{DOI}$, and ${ }^{3} \mathrm{H}-\mathrm{CN}$-IMI to $5-\mathrm{HT}_{1 \mathrm{~A}}, 5-\mathrm{HT}_{1 \mathrm{C}}$, and $5-\mathrm{HT}_{2}$ receptor subtypes and $5-\mathrm{HT}_{\mathrm{Up}}$ sites, respectively, in cat visual cortex are plotted as an average for all cortical regions and layers combined. The average density of receptor binding for each ligand, expressed as a proportion of maximal binding, was typically low at birth, increased to a maximum, at a different rate for each binding site, and then declined to adult levels. The peak binding levels to individual receptor subtypes exhibited surprisingly complementary temporal distributions, with $5-\mathrm{HT}_{1 \mathrm{~A}}$ receptors expressed at high levels earliest in development (PD10 $\mathrm{PD} 40$ ) followed by 5-HT $\mathrm{HC}_{\mathrm{C}}$ receptors (PD40-PD75), and the 5- $\mathrm{HT}_{2}$ receptor and 5-HT $\mathrm{Up}_{\mathrm{p}}$ sites later in development (PD75-PD120).

a different time course to temporally unique peak levels of expression, and then declined to adult levels. The $5-\mathrm{HT}_{1 \mathrm{~A}}$ receptors exhibited maximal levels of expression between PD20 and PD30 but dropped to near-adult levels by PD75. 5-HT $\mathrm{HC}_{\mathrm{C}}$ receptors also exhibited a transient peak in expression, which occurred slightly later, between PD40 and PD75, but then declined, by adulthood, to levels similar to that seen in early postnatal development. The expression of 5- $\mathrm{HT}_{2}$ receptors and $5-\mathrm{HT}_{\mathrm{Up}}$ sites increased gradually through early postnatal development, with a very similar time course, to exhibit their highest levels between PD40 and PD75. In both cases the highest levels of expression were maintained beyond PD120, but the reduction to adult levels was much greater for the $5-\mathrm{HT}_{2}$ subtype than for $5-\mathrm{HT}_{\mathrm{Up}}$ sites.

\section{Regional and laminar patterns}

In addition to displaying complementary temporal patterns of expression, individual 5-HT receptor subtypes demonstrated striking regional and laminar complementarity in their distributions. Developmental changes in the levels of expression of each 5-HT receptor subtype within individual regions, averaged across laminae, are expressed in the three-dimensional plots in Figure 5. The binding data for each radioligand, within individual laminae of each visual cortical region, are presented in Figure 6 . The quantitative changes in regional and laminar distributions described in the following sections can also be fol-

Figure 3. Autoradiographic images illustrating total binding of ${ }^{3} \mathrm{H}-$ $\mathrm{CN}-\mathrm{IMI}$ to $5-\mathrm{HT}_{\mathrm{U}}$ sites in visual cortex of PD20 $(A), \operatorname{PD} 75(B)$, and adult $(C)$ cats. $5-\mathrm{HT}_{\mathrm{Up}}$ sites exhibited a general increase in density with age; however, levels were essentially homogeneous across all cortical regions and laminae throughout early development but exhibited a slight preference over superficial layers in the adult. Scale bar, $2 \mathrm{~mm}$. 


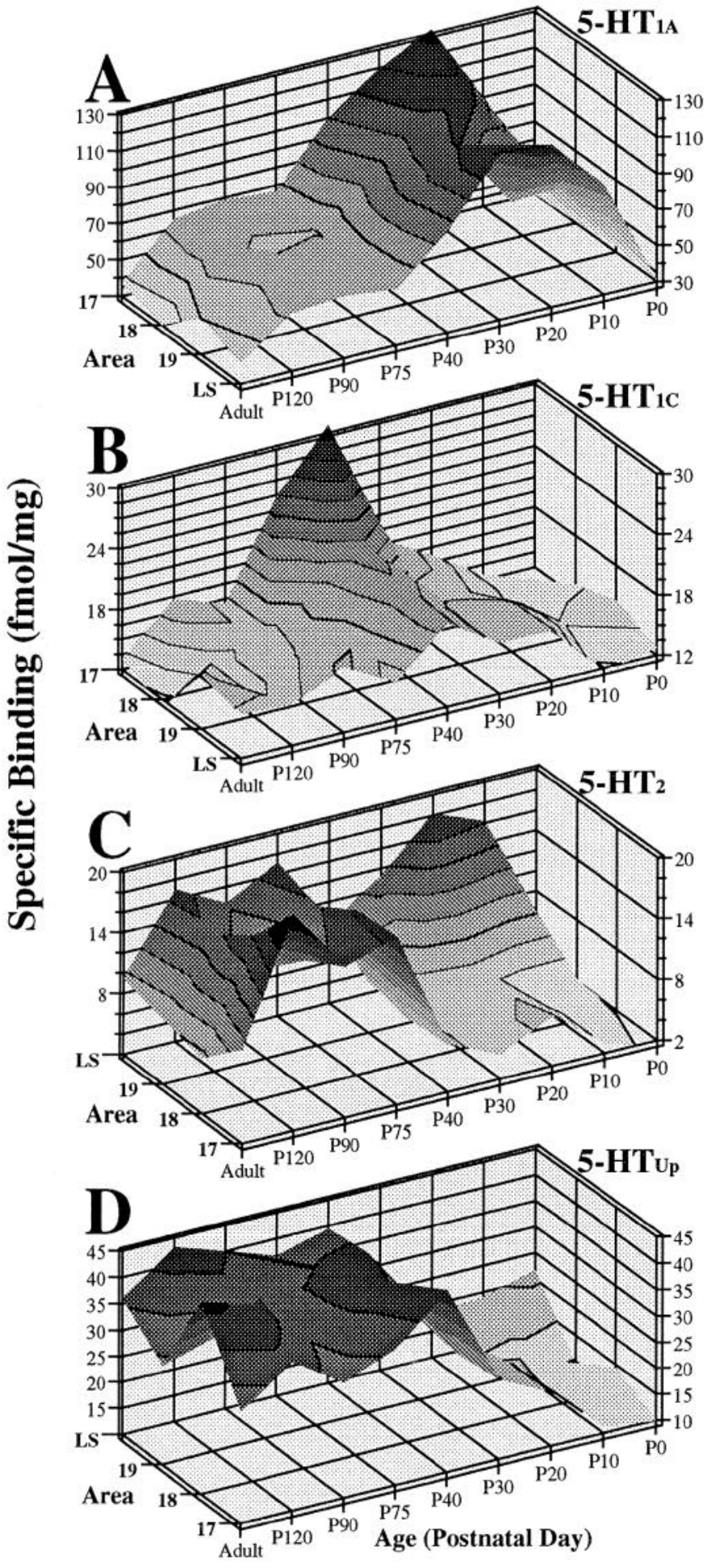

Figure 5. Three-dimensional plots demonstrating regional patterns in the distribution of 5- $\mathrm{HT}_{14}(A), 5-\mathrm{HT}_{1 C}(B)$, and 5- $\mathrm{HT}_{2}(C)$ receptors and $5-\mathrm{HT}_{U \mathrm{p}}$ sites $(D)$ during postnatal development of cat visual cortical areas 17,18 , and 19 , and LS. $A$, The temporal pattern in the distribution of $5 \mathrm{HT}_{1 \mathrm{~A}}$ receptors was similar across all visual cortical areas. From lowest levels at birth (PD0), the density of 5- $\mathrm{HT}_{1 \mathrm{~A}}$ receptors peaked between PD10 and PD30 and subsequently decreased to adult levels. $B$, Ligand binding specific for 5- $\mathrm{HT}_{1 \mathrm{C}}$ receptors was highest at PD40 and was essentially restricted to area $17 . C, 5-\mathrm{HT}_{2}$ receptors demonstrated highest levels of expression in LS at all postnatal ages beyond PD10 except for a striking decrease in level of expression at PD40. In areas 17, 18, and 19 peak levels were displayed between PD75 and PD120. D, Little regional disparity was seen in the distribution of 5- $\mathrm{HT}_{U \mathrm{p}}$ lowed qualitatively in the representative micrographs presented in Figures 1-3.

$5-H T_{1 A}$. The binding of ${ }^{3} \mathrm{H}-8-\mathrm{OH}-\mathrm{DPAT}$ to $5-\mathrm{HT}_{1 \mathrm{~A}}$ receptors was lowest at birth (PD0), with equally low levels distributed across all visual cortical areas (Figs. $5 A, 6 A$; area 17, $\bar{x}=27.68$ \pm 2.85 ; area 18, $\bar{x}=29.06 \pm 2.67$; area $19, \bar{x}=31.17 \pm 2.70$; $\mathrm{LS}, \bar{x}=28.39 \pm 2.66$ ). The majority of $5-\mathrm{HT}_{1 \mathrm{~A}}$ receptors in all four regions were localized to a narrow band below the CP that included layers V and VI and extended, only superficially, into the subplate (Figs. $6 A, 7 A$ ). The superficial layers, including the $\mathrm{CP}$ and layer 1, were equally labeled, at lower levels. A sharp increase in the level of binding was realized in all four regions between PD10 and PD30 (Figs. 5A, 6A). This increase in binding density was greater in areas 17 and $\operatorname{LS}(\bar{x}=105.89 \pm 6.96$, $108.29 \pm 7.26)$ than in areas 18 and $19(\bar{x}=95.67 \pm 6.13$, $98.76 \pm 6.22$ ) and was manifested by increases in receptor concentration predominantly in supragranular (I-III) and infragranular (V, VI) layers, although a significant increase was present in layer IV as well (Fig. 6A). The increase in binding was clearly visual cortex specific, distinguishing these areas from directly adjacent cortical regions (Figs. 1,2). The levels of 5-HT receptors peaked at $\mathrm{PD} 30$ with higher levels than those found at any other stage in development. The subsequent decline in expression seen beyond PD40 followed a similar time course across the different cortical regions (Figs. $5 \mathrm{~A}, 6 \mathrm{~A}$ ). By adulthood, in contrast, the visual cortex was conspicuously unlabeled relative to adjacent nonvisual areas. This regional disparity was due, primarily, to reduced numbers of $5-\mathrm{HT}_{1 \mathrm{~A}}$ receptors in cortical layers III, IV, V, and VI in areas $17 / 18(\bar{x}=37.40 \pm 2.38$, $30.44 \pm 2.67$ ), which distinguished them from the laterally adjacent area $19(\bar{x}=50.10 \pm 4.28)$ and the ventromedial cingulate cortex (Figs. 1, 5). A very narrow band within layer $\mathrm{V}$ was labeled at intermediate levels (Fig. 1, adult). The level of binding in the subplate and subcortical white matter was low at all ages (Figs. 1, 6A).

$5-H T_{l C} \cdot{ }^{3} \mathrm{H}$-mesulergine binding exhibited the greatest regional and laminar specificity of the subtypes analyzed in visual cortex (see Figs. 1, 11A). From Figures 1, 5B, and $6 B$, it is apparent that $5-\mathrm{HT}_{1 \mathrm{C}}$ binding sites exhibited their lowest levels of expression at birth within areas $17(\bar{x}=9.26 \pm 1.45), 18(\bar{x}$ $=13.22 \pm 1.45), 19(\bar{x}=14.51 \pm 1.45)$, and LS $(\bar{x}=12.76 \pm$ 1.45). Throughout development, the highest density of binding was limited exclusively to the middle cortical layers (Figs. 1, $6 B$ ). A denser band of receptors in the lowest portions of $\mathrm{CP}$, among cells destined for the base of layer IV (Shatz and Luskin, 1986), and upper layer $\mathrm{V}$ was distinguished from the equally dense binding in superficial and deep layers at birth (Figs. 1, $7 B$ ). The number of receptors increased slowly with age in areas $18(\bar{x}=15.98 \pm 1.45), 19(\bar{x}=17.24 \pm 1.45)$, and $\operatorname{LS}(\bar{x}=$ $17.01 \pm 1.45)$ but doubled in area $17(\bar{x}=18.55 \pm 1.45)$ by PD30 (Fig. 5B). A significant increase in specific binding of ${ }^{3} \mathrm{H}-$ mesulergine was observed at PD40 that was caused, almost entirely, by an increase in area $17(\bar{x}=31.03 \pm 3.00$; Fig. $5 B)$. Between PD30 and PD75, the pattern of ${ }^{3} \mathrm{H}$-mesulergine binding was characterized by a dense band located in deep layer IV/ superficial layer $\mathrm{V}$, from which emerged columns of receptors

sites. 5- $\mathrm{HT}_{U_{\mathrm{p}}}$ sites demonstrated a gradual increase in numbers from PD0 to PD40 and then maintained this high level to adulthood. Note that the left abscissa in plots $C$ and $D$ is reversed to make the relative binding in LS more visible than it would be otherwise. 


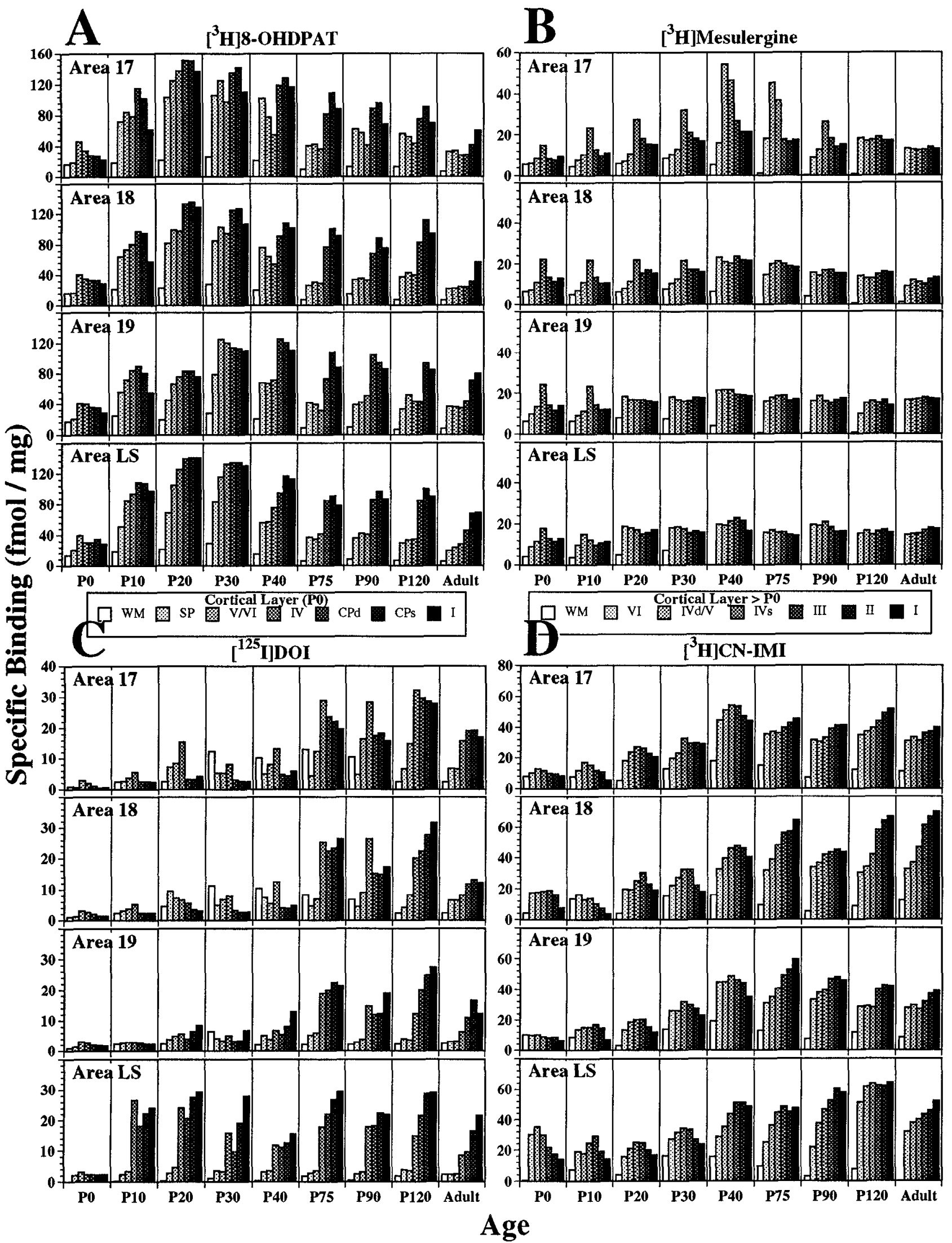

Figure 6. The bar graphs illustrate temporal changes in specific binding of ${ }^{3} \mathrm{H}-8$-OH-DPAT $(A),{ }^{3} \mathrm{H}$-mesulergine $(B)$, ${ }^{125} \mathrm{I}$-DOI $(C)$, and ${ }^{3} \mathrm{H}-\mathrm{CN}$ IMI $(D)$ in individual laminae within visual cortical areas 17, 18,19, and LS. A detailed description of their expression levels and patterns can be found in the text (see Results). 

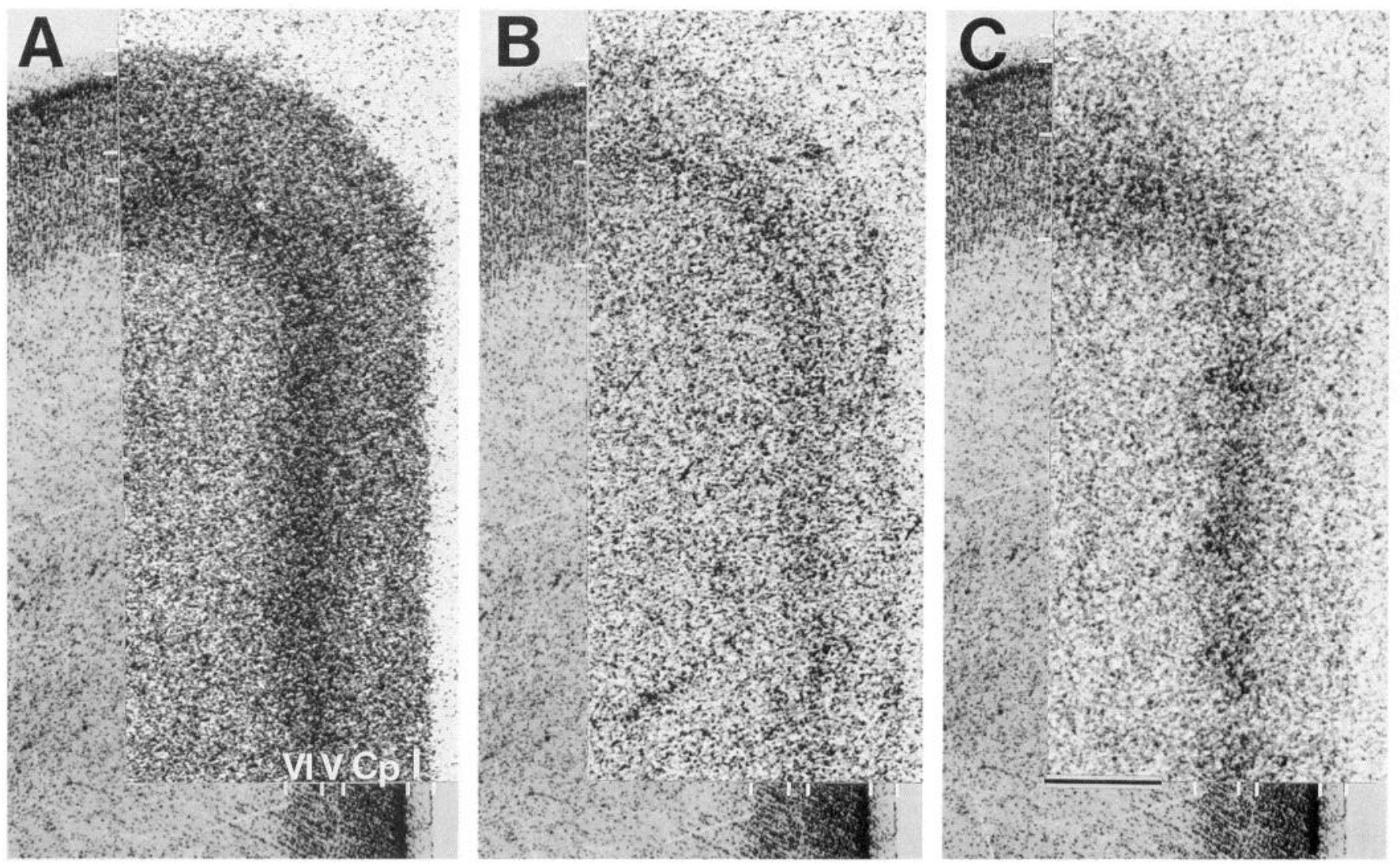

Figure 7. Photomontage showing the laminar distribution of 5- $\mathrm{HT}_{1 \mathrm{~A}}(A), 5-\mathrm{HT}_{1 \mathrm{C}}(B)$, and 5- $\mathrm{HT}_{2}(C)$ receptor subtypes in near-adjacent sections from kitten visual cortex (areas 17 and 18) at birth (PD0). Autoradiographic images are inset within a photomicrograph of the same tissue section stained with cresyl violet in order to indicate laminar boundaries. Peak expression of 5-HT $\mathrm{H}_{1 \mathrm{~A}}(A)$ and 5-HT $\mathrm{H}_{2}(C)$ receptors was limited to a single band within infragranular cortical layers $(\mathrm{V}-\mathrm{VI})$. 5 - $\mathrm{HT}_{\mathrm{IC}}$ receptors $(B)$ were also limited to a single band that was, however, positioned more superficially, extending from upper layer $\mathrm{V}$ to deeper levels of the cortical plate $(C p)$. Scale bar, $500 \mu \mathrm{m}$.

extending vertically into parts of layer III (Figs. 1, 6B). These high regional and laminar levels in the expression of $5-\mathrm{HT}_{1 \mathrm{C}}$ receptors were developmentally transient, peaking at PD40 and becoming reduced through PD75 $(\bar{x}=13.02 \pm 0.97)$ to near adult levels by PD90 $(\bar{x}=15.95 \pm 1.46)$. The reduction of columnar binding appeared gradual; remnants of 5-HT ${ }_{\mathrm{IC}}$ receptor columns were present only at the layer III/IV border at PD 90 (Fig. $1 G^{\prime}$ ). At ages beyond PD120, the distribution of $5 \mathrm{HT}_{1 \mathrm{C}}$ receptors in visual cortex was adult-like, essentially homogeneous across all layers (Figs. 1, 6B).

$5-H T_{2}$. The binding patterns of ${ }^{125}$ I-DOI binding displayed the greatest complexity in regional (see Figs. $1,5 C, 11 C$ ) and laminar (Fig. 6C) distributions, compared to that of the three 5-HT binding sites examined. The highest levels of 5- $\mathrm{HT}_{2}$ receptors, visualized with ${ }^{125}$ I-DOI, distinguished LS from adjacent cortical areas between PD10 $(\bar{x}=16.15 \pm 2.06)$ and PD75 $(\bar{x}=17.11 \pm 2.14)$. Except for a transient decrease at PD40 $(\bar{x}$ $=9.64 \pm 1.05$ ), their level of expression remained high through PD120 $(\bar{x}=16.98 \pm 2.17)$, after which they declined to adult levels $(\bar{x}=8.38 \pm 1.42)$. The level of $5-\mathrm{HT}_{2}$-specific binding in areas 17,18 , and 19 was lowest at birth $(\bar{x}=1.22 \pm 0.23$, $1.91 \pm .025,2.14 \pm 0.14)$ and then increased to intermediate levels by PD40 $(\bar{x}=6.73 \pm 0.72,6.28 \pm 0.67,7.07 \pm 0.64)$. Although at very low levels at birth, the expression of 5- $\mathrm{HT}_{2}$ receptors in lower cortical laminae appeared inhomogeneous and patchy (Fig. $7 \mathrm{C}$ ). Through early postnatal development (PD0-PD40), the highest concentrations of 5- $\mathrm{HT}_{2}$ receptors in areas 17,18 , and 19 were localized to the deeper cortical layers (IV, V, VI; Figs. 1, 6C). The highest laminar-specific density of receptors in areas $17 / 18$ was found in a band restricted to layer V/VI at birth (Fig. $7 C$ ) but highest in layer IV from PD10 to PD40 (Fig. 6C). A striking augmentation in the numbers of $5-\mathrm{HT}_{2}$ receptors in all visual cortical regions occurred between PD40 and PD75. They increased to peak levels, to values that were the highest of all cortical regions, in areas $17 / 18$ by PD75 $(\bar{x}=18.46 \pm 1.79,14.52 \pm 1.95)$ and continuing through PD120 $(\bar{x}=23.25 \pm 2.23,18.22 \pm 2.24)$, before declining to adult levels $(\bar{x}=11.19 \pm 1.52,7.47 \pm 0.94)$. The laminar pattern of expression changed significantly over this period, becoming predominant in superficial layers. In areas 17 and 18, the highest density of binding was always localized to a band within superficial levels of layer IV (Fig. 6C). Among the different 5-HT subtypes, the $5-\mathrm{HT}_{2}$ receptors were found unusual in demonstrating high levels of expression in white matter (Figs. 1, 6C). The binding in subcortical white matter was transient, reaching its highest levels at PD30 within a narrow band directly subadjacent to layer VI (Fig. 1). This localization of 5- $\mathrm{HT}_{2}$ receptors was observable through PD 90 but was never seen in the adult.

$5-H T_{U p}$. The expression of 5-HT $\mathrm{U}_{\mathrm{Up}}$ sites closely matched the regional and temporal trends described for the $5-\mathrm{HT}_{2}$ receptors (Fig. 5D); however, unlike all other 5-HT receptors subtypes, the distributions of $5-\mathrm{HT}_{\mathrm{Up}}$ did not exhibit a great degree of laminar disparity (Figs. 3, 6D). In the later stages of postnatal development there were discernably higher levels of expression 
Figure 8. These densitometric profile plots illustrate the changing levels of $5-\mathrm{HT}_{1 \mathrm{~A}}, 5-\mathrm{HT}_{1 \mathrm{C}}$, and $5-\mathrm{HT}_{2}$ receptors as a function of postnatal development. For each age, specific binding density is displayed as a proportion of peak binding. The positions of cortical laminae are indicated by Roman numerals $(I-V I) ; C p$, cortical plate.
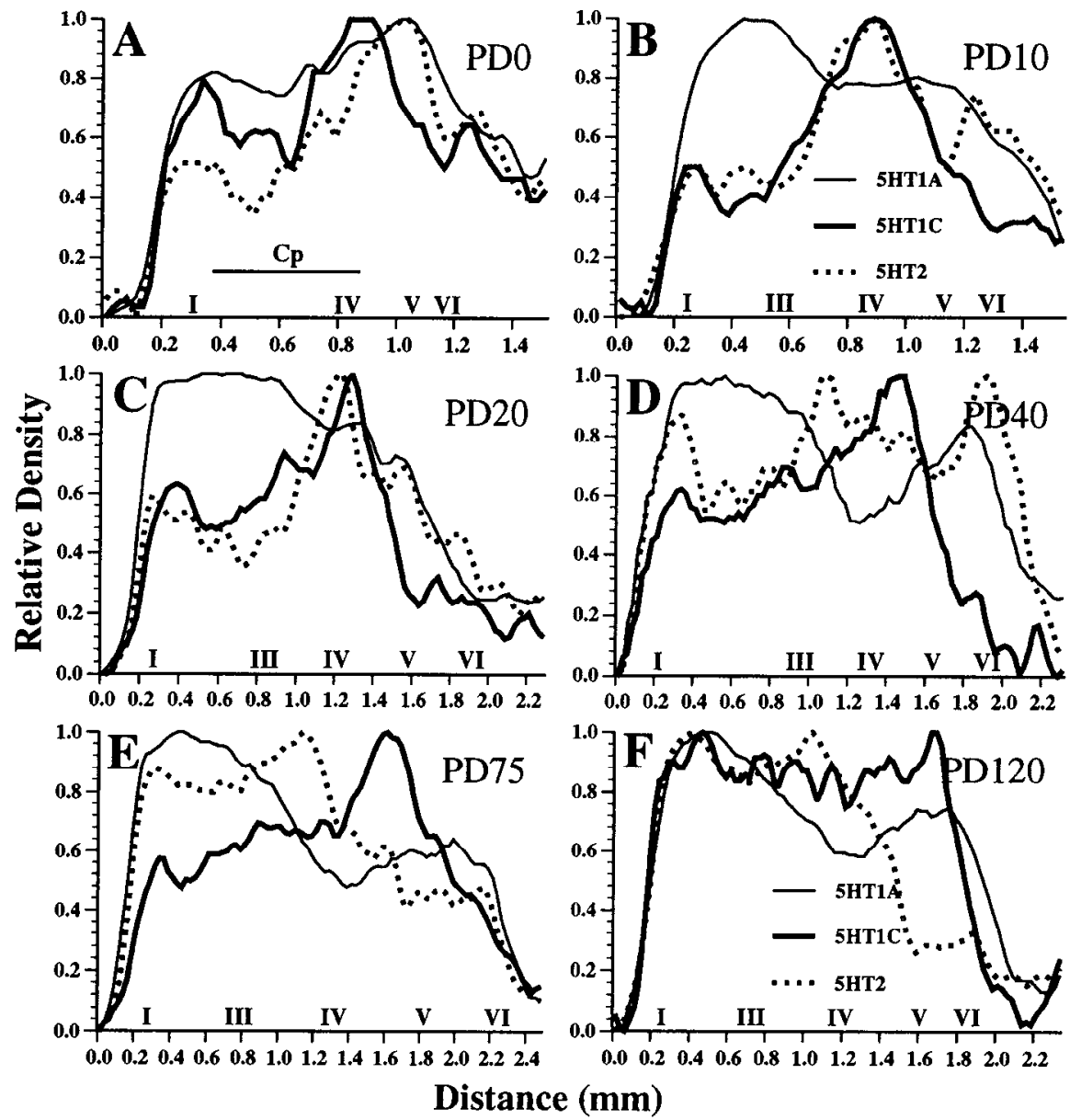

in supragranular layers, particularly in area 18 (Figs. 3, 6D). It is apparent from Figure $5 D$ that, at early postnatal ages, the highest density of $5-\mathrm{HT}_{\mathrm{Up}_{\mathrm{p}}}$ was localized to $\mathrm{LS}(\bar{x}=21.58 \pm$ $2.24)$, with the lowest in area $19(\bar{x}=9.30 \pm 1.14)$ followed by area $17(\bar{x}=9.98 \pm 0.94)$ and area $18(\bar{x}=14.39 \pm 1.11)$. The levels of expression increased progressively in all areas and by PD40 uptake sites were found at high levels, across all cortical areas $(17,44.61 \pm 2.46 ; 18,38.40 \pm 2.82 ; 19,40.47 \pm 2.12$ LS, $39.37 \pm 2.47$ ). These levels of expression were essentially maintained throughout the remainder of postnatal visual cortical development (Fig. 5D). The general trend for all regions to exhibit decreases in receptor expression between PD 120 and adult was maintained for the $5-\mathrm{HT}_{\mathrm{Up}}$ site, but to a far lesser degree, in areas 17, 19, and LS (Fig. 5D). In fact, as is apparent in Figures $5 D$ and $6 D$, the density of $5-H_{U_{p}}$ sites increased slightly in area 18 from PD120 $(\bar{x}=43.48 \pm 3.94)$ to adult levels $(\bar{x}=46.66 \pm 3.94)$.

Complementary patterns of expression. A recurring theme in the developmental distribution of the multiple 5-HT receptor subtypes was complementarity of laminar expression. This feature was found to be most conspicuous in area 17. In Figure 8 , the profile plots illustrate densitometric changes in binding of ${ }^{3} \mathrm{H}-8$-OH-DPAT, ${ }^{3} \mathrm{H}$-mesulergine, and ${ }^{225} \mathrm{I}-\mathrm{DOI}$ across cortical laminae within area 17 expressed as a proportion of peak binding for six representative ages between PDO and adulthood. The distributions of 5-HT $\mathrm{U}_{\mathrm{D}}$ sites did not exhibit significant laminar variation in area 17 and were not included to simplify visual comparisons. At $\mathrm{PDO}$, only the $5-\mathrm{HT}_{1 \mathrm{C}}$ receptors exhibited a specific laminar distribution (layer IV) that would be main- tained through subsequent stages in development. While 5-HT receptors were predominant deep within the cortical plate, among prospective layer IV cells (Figs. $7 B, 8 A$ ), the $5-\mathrm{HT}_{1 \mathrm{~A}}$ (Fig. $7 A$ ) and $5-\mathrm{HT}_{2}$ (Fig. $7 C$ ) receptors were concentrated within the same, deeper, infragranular laminae (Fig. $8 A$ ). Beginning at PD 10 (Fig. $8 B$ ) and continuing throughout the remainder of postnatal development, the highest levels of $5-\mathrm{HT}_{\mathrm{IA}}$ receptors were concentrated in supragranular laminae (I-III). On the other hand, the highest levels of $5-\mathrm{HT}_{1 \mathrm{C}}$ and $5-\mathrm{HT}_{2}$ receptors were consolidated in layer IV. Between PD10 (Fig. 8B) and PD20 (Fig. 8C) they were localized to the same laminae, but by PD40 (Fig. $8 D$ ) their relative distributions were changed. $5-\mathrm{HT}_{1 \mathrm{C}}$ receptors were maintained in deeper strata of layer $I V$, but the $5-\mathrm{HT}_{2}$ receptors were now concentrated in upper layer IV. This relationship was maintained beyond PD75 (Fig. $8 E$ ), as long as both receptor subtypes were present. By PD120 the distribution of $5-\mathrm{HT}_{1 \mathrm{C}}$ receptors was essentially homogeneous across different cortical laminae but the highest density of $5-\mathrm{HT}_{2}$ receptors was distributed through layers I-IV (Fig. $8 F$ ). The strong overall tendency in all the panels of Figure 8 is for the concentration of each binding site to peak in different layers and at different cortical depths. The complementarity in the laminar binding profile is most pronounced during intermediate ages examined (Fig. $8 \mathrm{C}$ $E, \mathrm{PD} 20-\mathrm{PD} 75)$.

\section{Columnar distribution of 5-HT receptors}

Between PD30 and PD90, 5-HT 1 and 5- $\mathrm{HT}_{2}$ receptors were augmented in a periodic manner within layer IV of area 17. Although the patterned expression of these receptors was first 
apparent at PD30, it was weak and not always readily demonstrable until after PD40, at ages when both receptor subtypes were found in greater abundance in area 17. Because of this developmental profile, we chose to concentrate on PD50 kittens to study the columnar distributions of $5-\mathrm{HT}_{\mathrm{IC}}$ and $5-\mathrm{HT}_{2}$ receptor subtypes.

Columns of 5-HT ${ }_{1 \mathrm{C}}$ receptors emerged from a dense band of $5-\mathrm{HT}_{1 \mathrm{C}}$ receptors at the layer IV/V interface and extended radially, through the entire extent of layer IV, and up into the deepest levels of layer III (see Figs. 9B, 10C). This distinct distribution of $5-\mathrm{HT}_{1 \mathrm{C}}$ receptors was strictly limited to area 17 (see Fig. $10 C$ ). The patterned distribution of $5-\mathrm{HT}_{2}$ receptors resembled beady excrescences radiating from a dense band, more so than columns (see Figs. $9 C, 10 D$ ). This band was consolidated within upper strata of layer IV and lower strata of layer III (see Fig. 9C) in area 17 and area 18 (see Fig. 10D). However, the bead-like pattern of expression was not readily apparent in area 18 .

The spatial relationship between the patchy $5-\mathrm{HT}_{1 \mathrm{C}}$ and $5-\mathrm{HT}_{2}$ receptor distributions is apparent in Figure 10,C and $D$, and at higher magnification in the serially adjacent sections in Figure $9, B$ and $C$. The patches of increased $5-\mathrm{HT}_{1 \mathrm{C} / 2}$ receptor density were found to be precisely in register, within the same vertical column (Fig. 9B,C, arrows). Although the highest density of each of these 5-HT receptor subtypes was centered within different substrata of layer IV, their patchy pattern of expression was precisely coaligned, where they were overlapped in upper layer IV (Figs. 9B,C; $10 C, D$, arrowheads).

The overall columnar distributions of 5-HT receptors in area 17 are best appreciated in parasagittal (Fig. 11) and tangential (Fig. 12) sections through layer IV of a PD50 kitten. The patchy distribution of $5-\mathrm{HT}_{1 \mathrm{C}}$ receptors at this age was strictly limited, in the neocortex, to visual cortical area 17 (Figs. 11 $A, 12$ ). In sections tangential to the unfolded cortical surface (Fig. 12), patches of 5-HT $\mathrm{H}_{1 \mathrm{C}}$ receptors, with an average diameter of approximately $400 \mu \mathrm{m}(\bar{x}=418 \pm 18)$, were found distributed throughout area 17 with an average center-to-center spacing of approximately $900 \mu \mathrm{m}(\bar{x}=909 \pm 211)$. In addition to dis-

\footnotetext{
Figure 9. Higher-magnification photomicrographs demonstrating laminar and intralaminar relationships in the distributions of $5-\mathrm{HT}_{1 \mathrm{~A}}$ $(A), 5-\mathrm{HT}_{1 C}(B)$, and $5-\mathrm{HT}_{2}(C)$ receptors and $5-\mathrm{HT}_{\mathrm{Up}}(E)$ sites in nearadjacent sections from PD50 kitten visual cortex (area 17). 5-HT receptors were densely distributed throughout supragranular (I-III) and to a lesser degree in infragranular (V-VI) cortical laminae. The highest densities of $5-\mathrm{HT}_{1 \mathrm{C}}$ and $5-\mathrm{HT}_{2}$ receptors were found in middle layers. In addition to displaying a complementary laminar arrangement with $5-\mathrm{HT}_{1 \mathrm{~A}}$ receptors, $5-\mathrm{HT}_{1 \mathrm{C}}$ and $5-\mathrm{HT}_{2}$ receptors demonstrated an intralaminar complementarity with the highest density of $5-\mathrm{HT}_{1 \mathrm{C}}$ receptors located within deeper levels of layer IV and 5- $\mathrm{HT}_{2}$ receptors predominant in superficial layer IV. Moreover, both receptor subtypes exhibited a patchy appearance within layer IV. These patches were $\sim 400 \mu \mathrm{m}$ in diameter and spaced $\sim 900 \mu \mathrm{m}$ apart and were localized to the same vertical column ( $B$ and $C$, arrows). The columnar expression of 5-HT and 5- $\mathrm{HT}_{2}$ receptors also extended into the deeper portions of layer III. In addition to peak levels in superficial strata of layer IV, 5- $\mathrm{HT}_{2}$ receptors exhibited intermediate levels of expression in layers I-III, lower layer IV, and subcortical white matter $(w m) . E$ shows that the distribution of 5-HT $\mathrm{H}_{\mathrm{U}_{\mathrm{p}}}$ sites was essentially uniform across all cortical laminae. The borders of cortical laminae (I-VI) and subcortical white matter $(\mathrm{wm})$ are indicated at the edge of each panel with reference to the Nisslstained section $(D) . B$ and $C$ are from serially adjacent sections. The distance of each section from that in $A$ is indicated $(\mu \mathrm{m})$ in the lower left of each figure. $D$ and $E$ are from the same section that was Nisslstained following autoradiographic processing. Scale bar, $1.0 \mathrm{~mm}$.
}
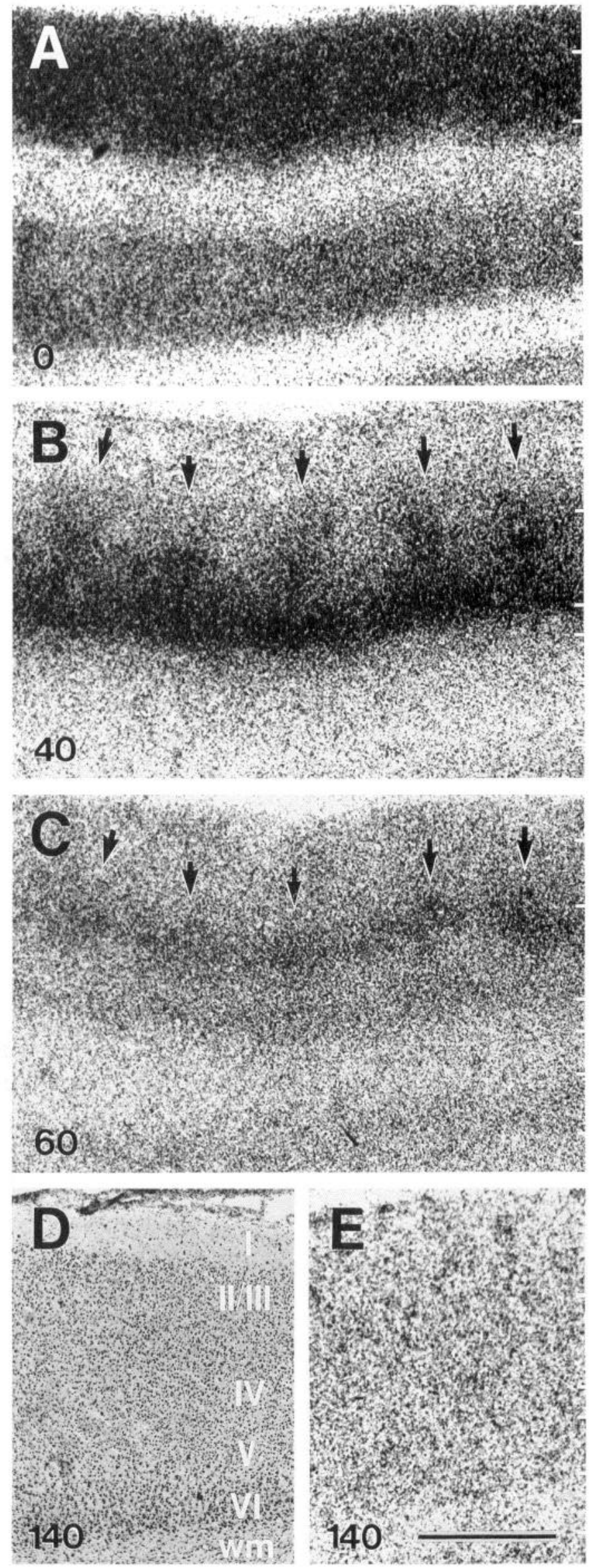

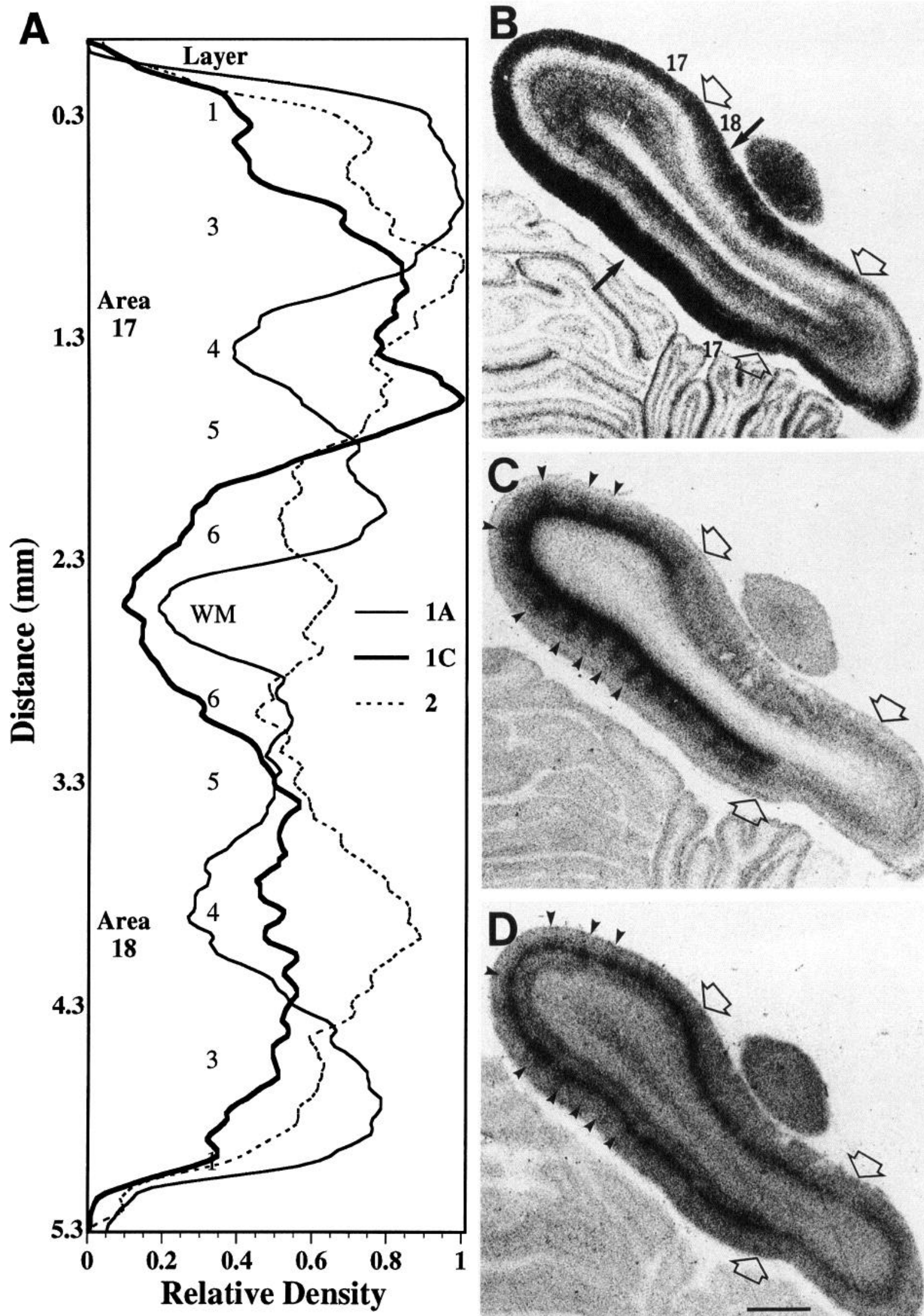

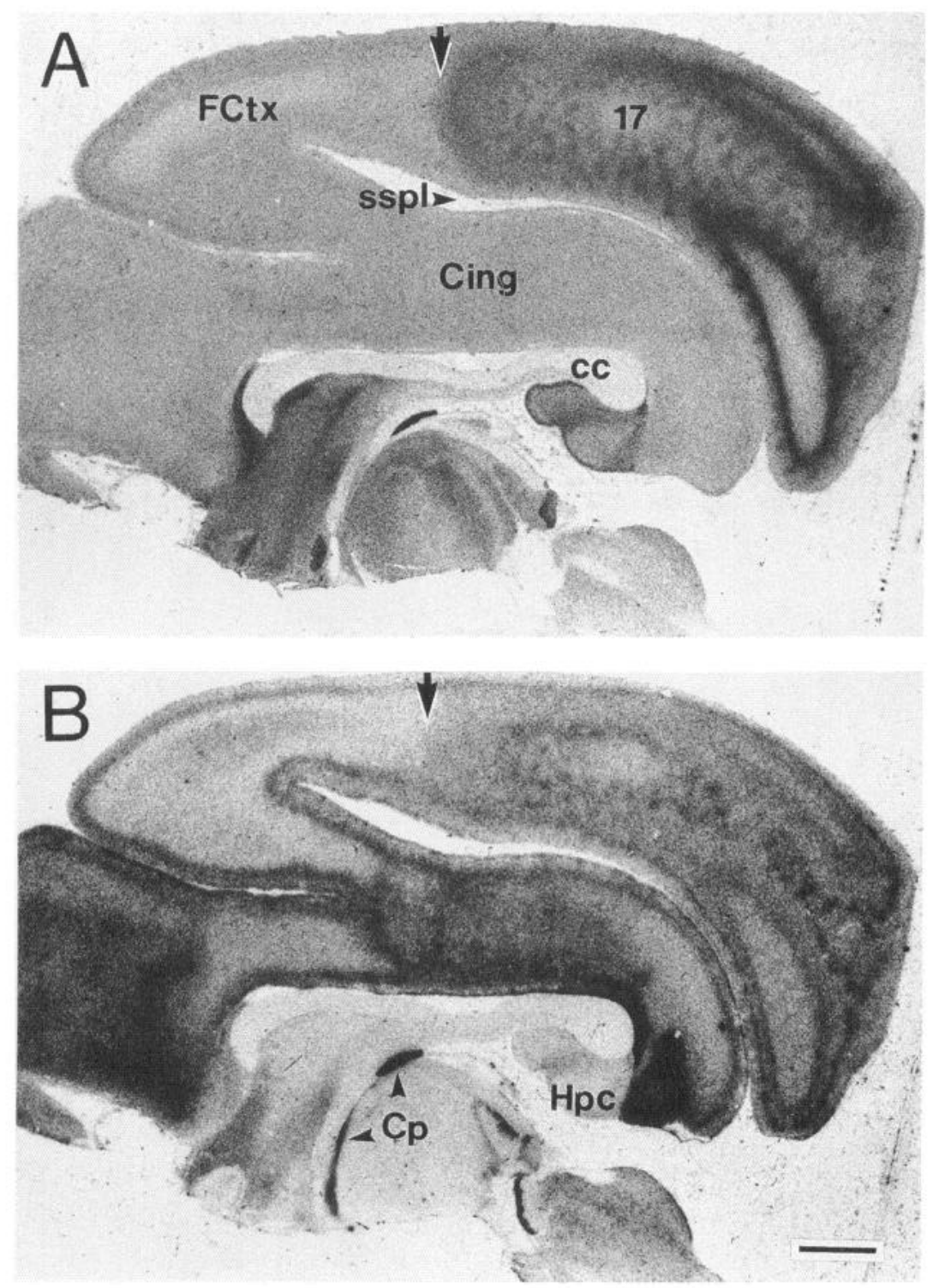

Figure 11. The distribution of $5-\mathrm{HT}_{1 \mathrm{C}}$ receptors, labeled with ${ }^{3} \mathrm{H}$-mesulergine $(A)$, and $5-\mathrm{HT}_{2}$ receptors, labeled with ${ }^{125}$ I-DOI $(B)$ in adjacent, parasagittal sections through PD50 kitten brain. Each of these subtypes of the 5- $\mathrm{HT}_{2}$ receptor family exhibited distinctly different regional and laminar localizations. In area 17, high levels of both $5-\mathrm{HT}_{1 \mathrm{C}}$ and $5-\mathrm{HT}_{2}$ receptors exhibited a periodic distribution. However, while the highest density of $5-\mathrm{HT}_{\mathrm{IC}}$ receptors was limited to visual cortical area 17 at this age, 5- $\mathrm{HT}_{2}$ receptors were more broadly distributed within other cortical (e.g., FCtx, frontal cortex; Cing, cingulate cortex; $H p c$, hippocampus) and subcortical regions. The arrows indicate the anterior extent of visual cortical area 17. $C p$, choroid plexus; $c c$, corpus callosum; sspl, suprasplenial sulcus. Scale bar, $3 \mathrm{~mm}$.

tinctive distributions in visual cortices (Fig. 10D), high levels of $5-\mathrm{HT}_{2}$ receptors were observed across a number of different cortical (e.g., FCtx, Cing, Hpc) and subcortical regions in the kitten brain (Fig. 11B). Measurements of area 17 from the two hemispheres that were opened and flattened indicate that the surface area of area 17 in PD50 kittens is approximately 312 $\mathrm{mm}^{2}(306,318)$, which is similar to values previously published in the adult (Tusa et al., 1978; Van Essen and Maunsell, 1980; Olavarria and Van Sluyters, 1985). The total number of 5-HT $\mathrm{HC}_{1 \mathrm{C}}$ rich patches within area 17 of each hemisphere was 296 and 315 , respectively, which suggests a packing density of approx- imately 1 patch $/ \mathrm{mm}^{2}$. These patches did not appear to be aligned along any particular axis, nor was their periodicity significantly different across area 17.

\section{Discussion}

The results of this study reveal that four 5-HT receptor subtypes are expressed in unique and complementary temporal, regional, laminar, and intralaminar patterns in developing cat visual cortex. 5-HT ${ }_{1 \mathrm{~A}}$ receptors reached peak levels between PD10 and PD30 and were concentrated in superficial (I-III) and in deep (V, VI) laminae of all visual cortical areas. The 5- $\mathrm{HT}_{1 \mathrm{C}}$ and

Figure 10. Autoradiographic images showing the regional and laminar complementarity of 5-HT $1 \mathrm{~A}(B), 5-\mathrm{HT}_{1 \mathrm{C}}(C)$, and 5-HT ${ }_{2}(D)$ receptors in near-adjacent sections from PD50 visual cortex. The profile plot in $A$, generated from a densitometric slice through cortical areas 17 and 18 at the level of the solid arrows in $B$, compares laminar changes in binding density among the three receptor subtypes. 5-HT 1 receptors were most highly concentrated in supragranular layers and of intermediate density within infragranular layers. A high density of $5-\mathrm{HT}_{2}$ receptors was demonstrated in supragranular and granular layers of both areas 17 and 18, with a band of peak binding limited to superficial levels of layer IV. Peak expression of 5- $\mathrm{HT}_{1 \mathrm{C}}$ receptors was localized to the deeper half of layer IV, and was limited to area 17. Both 5-HT $\mathrm{H}_{1 \mathrm{C}}$ and 5-HT $\mathrm{H}_{2}$ receptor subtypes exhibited a patchy distribution, but within different strata of layer IV, in the same vertical column (arrowheads indicate coincident columnar localizations). The borders of areas 17 and 18 are indicated by the open arrows. Scale bar, $2.0 \mathrm{~mm}$. 

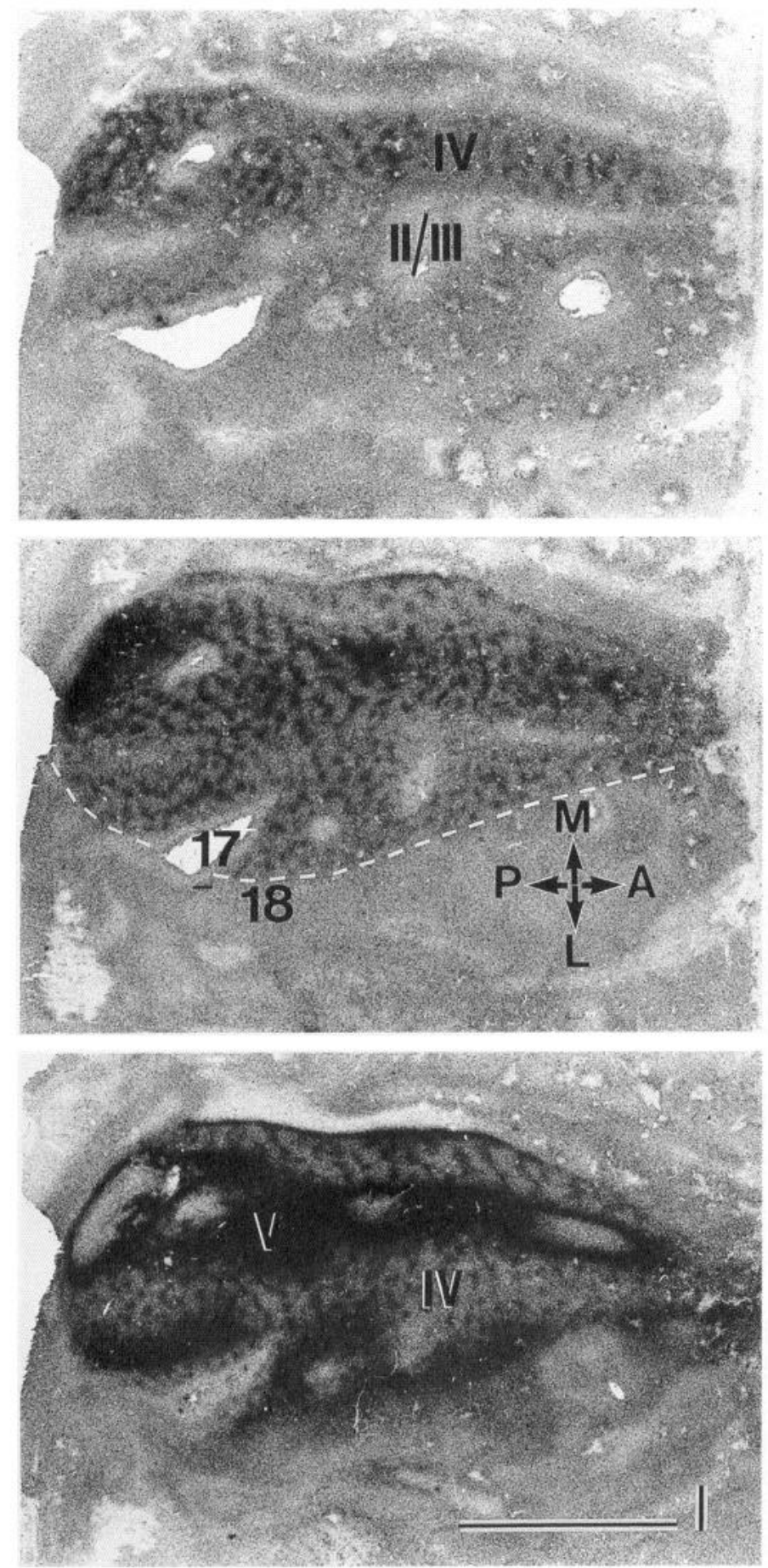

Figure 12. The tangential distribution of $5-\mathrm{HT}_{1 \mathrm{C}}$ receptors in visual cortex at PD50, in sections taken at 400,640, and $1000 \mu \mathrm{m}$ (top, middle, bottom panels, respectively) from the surface of a flattened right hemisphere. The overall patchy distribution of $5-\mathrm{HT}_{1 \mathrm{C}}$ receptors in the neocortex was limited to visual cortical area 17. Patches of $5-\mathrm{HT}_{\mathrm{IC}}$ receptors averaged $400 \mu \mathrm{m}$ in diameter and were separated by an average centerto-center spacing of $900 \mu \mathrm{m}$. It is apparent from these sections that columns of 5-HT 1 receptors extended from deeper levels of layer III (top) through the entire extent of layer IV and disappeared in a dense band of binding at the layer IV/V border (bottom). The broken line indicates the approximate position of the area $17 / 18$ border. $M$, ventromedial; $L$, dorsolateral; $A$, anterior; $P$, posterior. Scale bars: $10 \mathrm{~mm}$ and $2 \mathrm{~mm}$.
$5-\mathrm{HT}_{2}$ receptor subtypes displayed their highest levels between PD40-PD75 and PD75-PD120, respectively, within different strata of layer IV. While $5-\mathrm{HT}_{\mathrm{IC}}$ receptors were restricted to area $17,5-\mathrm{HT}_{2}$ receptors were highly expressed in area 17,18 , and LS. Although $5-\mathrm{HT}_{U \mathrm{p}}$ sites exhibited significant increases in level of expression throughout postnatal development, they did not demonstrate notable regional or laminar disparity until adulthood.

A striking result of these studies was the finding that peak concentrations of 5- $\mathrm{HT}_{1 \mathrm{C}}$ and $5-\mathrm{HT}_{2}$ receptors demonstrated transient columnar distribution within layer IV of area 17 in developing visual cortex. Additionally, their differential intralaminar and regional distributions offered novel evidence regarding a potential relationship of their columnar organization in visual cortex to functional afferent pathways. These results are discussed, in the following sections, with regard to comparative 5-HT receptor-specific binding studies and the functional anatomy of the developing visual cortex.

\section{Methodological considerations}

The ligand concentrations and incubation parameters we used were determined from previously published studies that had characterized these ligands in a number of different species, but predominantly in adult animals. As a consequence, we cannot be certain whether the variations in binding density that we observed reflect changes in receptor number $\left(B_{\max }\right)$ or in changes in receptor affinity $\left(K_{d}\right)$. Other studies, which have characterized developmental changes in 5-HT receptor expression, have reported ontogenetic changes in binding to be exclusively due to changes in their number, and not affinity (Gross-Isseroff et al., 1990; Biegon, 1991). However, this cannot simply be assumed to be true in cats as well. Regardless of which of these possibilities is correct, the densitometric changes in receptor binding that we have described are likely to reflect, at some level, the efficacy with which each receptor subtype binds to the endogenous ligand. However, a complete pharmacological characterization of these ligands at each age studied would be required to address these possibilities definitively.

The pharmacological and molecular characteristics of 5-HT and $5-\mathrm{HT}_{2}$ receptors are very similar, and several studies have indicated that currently available ligands lack subtype specificity (Closse, 1983; Glennon et al., 1992). However, the reported lack of specificity of ${ }^{3} \mathrm{H}$-mesulergine for $5-\mathrm{HT}_{1 \mathrm{C}}$ receptors in rats (Closse, 1983; Pazos et al., 1988) differs from studies in human and porcine brain, where the binding of ${ }^{3} \mathrm{H}$-mesulergine was 5-HT ${ }_{\text {IC }}$ specific (Paos et al., 1984a, 1988; Lyon and Tietler, 1988). Several lines of evidence indicate that the specificity of ${ }^{3} \mathrm{H}$-mesulergine and ${ }^{125} \mathrm{I}$-DOI binding for the $5-\mathrm{HT}_{1 \mathrm{C}}$ and $5-\mathrm{HT}_{2}$ subtypes, respectively, holds true in cats as well. First, the distinctly different temporal and spatial distributions of ${ }^{3} \mathrm{H}-\mathrm{me}-$ sulergine and ${ }^{125} \mathrm{I}$-DOI binding indicate that these ligands label different populations of receptors. The inclusion of spiperone, which has a 1000 -fold lower affinity to $5-\mathrm{HT}_{1 \mathrm{C}}$ than $5-\mathrm{HT}_{2}$ receptors, in the incubation medium has been used to confer greater specificity of ${ }^{3} \mathrm{H}$-mesulergine for $5-\mathrm{HT}-_{1 \mathrm{IC}}$ receptors. In the present study, we found no differences in the regional and temporal binding patterns exhibited by ${ }^{3} \mathrm{H}$-mesulergine binding in cat visual cortex, with or without the inclusion of spiperone. Finally, the temporal and regional patterns in the expression of $5-\mathrm{HT}_{2}$ sites were identical when either ${ }^{125} \mathrm{I}-\mathrm{DOI}$ or ${ }^{3} \mathrm{H}-\mathrm{DOB}$ was used. These data do not, however, rule out the possibility that ${ }^{3} \mathrm{H}$-mesulergine and ${ }^{125} \mathrm{I}$-DOI differentiate different affinity states 
of the 5-HT $1 \mathrm{C}$ and/or the 5-HT $\mathrm{HT}_{2}$ receptor, or the existence of additional subtypes within the $5-\mathrm{HT}_{2}$ family (Lyon and Titeler, 1988; Leonhardt and Teitler, 1989; Pierce and Peroutka, 1989; Hartig et al., 1990; Titeler et al., 1990). Further pharmacological characterization, complemented by in situ hybridization studies, is required to address these issues fully.

\section{Columnar segregation}

Perhaps the most significant implication that emerges from the results of this study relates to the transient columnar expression of $5-\mathrm{HT}_{1 \mathrm{C}}$ and $5-\mathrm{HT}_{2}$ receptors in area 17 and, consequently, the potential role they may play in the formation of functional cortical columns, such as those related to ocular dominance, orientation, or some other columnar property of visual cortex during development.

Other columnar markers. Despite abundant physiological evidence for the existence of functionally similar columnar compartments among primates and carnivores, endogenous, anatomical markers of any columnar organization in nonprimate striate cortex had not been described (see LeVay and Nelson, 1991, for review). The discovery that cytochrome oxidase (CO) blobs are present in the visual cortex of adult cats (Murphy et al., 1990) and ferrets (Cresho et al., 1992), combined with evidence of a columnar distribution of 5'-nucleotidase (Schöen et al., 1990), CO (Dyck and Cynader, 1992, 1993), AChE (Dyck and Cynader, 1992, 1993), 5-HT receptors (Dyck and Cynader, 1990a,b, 1993), and synaptic zinc (Zn) (Dyck and Cynader, $1989,1992,1993$; Dyck et al., 1993a,b) in young kittens, indicates that this is no longer the case.

The distribution of synaptic zinc, a vesicular component of a subset of glutamatergic terminals in cat visual cortex (Beaulieu et al., 1992), is enriched in columns within layer IV of area 17 (Dyck et al., 1993). When compared in serially adjacent sections, $\mathrm{Zn}$-rich columns are precisely coaligned with the $5-\mathrm{HT}_{\mathrm{IC}}$ receptor columns described here (Dyck and Cynader, 1992, 1993). Moreover, we have recently demonstrated that $\mathrm{CO}$ blobs in kitten visual cortex are coaligned with patches of increased staining for $\mathrm{AChE}$, and that the distribution of these CO/AChE blobs is precisely complementary to 5-HT receptor/Zn columns (Dyck and Cynader, 1992, 1993).

The distribution of numerous columnar markers, and their relationships to $\mathrm{CO}$ blob or interblob zones, and to the functional organization of visual cortex, have been extensively studied in primate striate cortex (see LeVay and Nelson, 1991, for review), but functional correlates of cortical columns in the cat have not yet been described. We have recently demonstrated that $\mathrm{Zn}$ is also distributed inhomogeneously in primate striate cortex in a manner that is, both tangentially and laminarly, precisely complementary to $C O$ (Dyck and Cynader, 1992, 1993; Dyck et al., 1993b). In combination with the demonstration that the serotonergic innervation of striate cortex is more abundant outside of CO blobs (Hendrickson, 1985), these studies indicate the possibility that a phylogenetic conservation of columnar markers in striate cortex may also reflect parallel functional compartmentalizations. A key question concerns the nature and properties of the columnar system(s) demarcated by the 5-HT receptors. In primates the $\mathrm{CO}$ blobs have been associated with several distinct functional and anatomical properties, including color specificity, ocular dominance, zones of low orientation selectivity, and differential inputs and output connectivity (Livingstone and Hubel, 1984a,b). Since the 5-HT receptor columns reported here are precisely complementary to the $\mathrm{CO}$ blobs of the cat cortex, some of the same functional properties may be defined by the 5-HT system in development. Of the various features in primate, color specificity is the least likely candidate to be defined by $5-\mathrm{HT}$ receptors in cats. This is because cats have rather poor color vision (Daw, 1973), and also because of evidence from nocturnal primates that indicates the presence of $\mathrm{CO}$ blobs, even in the absence of color selectivity (Condo and Casagrande, 1990).

Ocular dominance. In old-world monkeys, $\mathrm{CO}$ blobs are in the centers of ocular dominance columns and the same relationship may apply in cats. The temporal characteristics of the patchy distribution of $5-\mathrm{HT}_{1 C}$ and $5-\mathrm{HT}_{2}$ receptors parallel the time course for the developmental plasticity of ocular dominance columns. The first signs of $5-\mathrm{HT}_{\mathrm{IC}}$ columns are evident around PD30, shortly after the eye-specific geniculate afferents begin to segregate in layer IV (LeVay et al., 1978), and their columnar expression is highest through the developmental period during which ocular dominance columns are most sensitive to manipulations of visual input (Hubel and Wiesel, 1962; Cynader et al., 1980; Olson and Freeman, 1980; Jones et al., 1984). However, the spatial distributions of 5-HT receptor columns are not consistent with a direct relationship to ocular dominance. Anatomical and physiological studies indicate that ocular dominance columns are spaced about $0.5 \mathrm{~mm}$ center-to-center, fully one-half that of 5-HT receptor columns (Shatz et al., 1977; LeVay et al., 1978; Shatz and Stryker, 1978; Löwel and Singer, 1987; Anderson et al., 1988), a result that is substantiated by quantitative data showing that each cortical hemisphere contains approximately 600 ocular dominance columns (Anderson et al., 1988). Instead, we estimate that each visual cortex contains around 300 5-IIT receptor columns. Moreover, 5-HT $\mathrm{HC}_{1 \mathrm{C}}$ receptors are only found in area 17 , while ocular dominance columns are represented in areas 17 and 18 . Finally, we have shown by direct comparison, in the same cortical section, that the distributions of synaptic Zn-rich columns, which are coaligned with 5-HT receptor columns in area 17 , are not explicitly related to ocular dominance columns labeled transneuronally by intraocular injections of ${ }^{3} \mathrm{H}$-proline (Dyck and Cynader, 1992, 1993).

Oricntation. In terms of their average center-to-center spacing, 5-HT receptor columns appear to be more closely related to the orientation column system in cats (Hubel and Wiesel, 1962; Löwel et al., 1988). However, metabolic mapping studies of the orientation column system in cat visual cortex using ${ }^{14} \mathrm{C}$ deoxyglucose describe a regular system of parallel bands whose trajectory is orthogonal to the area $17 / 18$ border (Löwel et al., 1987; Swindale et al., 1987). We do not find that 5-HT receptor columns are found in bands, nor do they appear oriented along any preferred axis (see Fig. 12). However, previous studies have indicated singularities in the cat and monkey cortical orientation maps, zones where different orientation bands coalesce and which contain broadly tuned neurons (Blasdel and Salama, 1986; Swindale et al., 1987; Bonhoeffer and Grinvald, 1991). These singularities are thought to be associated with $\mathrm{CO}$ blobs in monkeys (Blasdel, 1992) and may well have the same association in cat cortex. Since the 5 -HT receptor columns are complementary to the $\mathrm{CO}$ blobs, these results imply that 5 -HT receptor columns distinguish neurons in the visual cortex that may show a relatively high degree of orientation tuning.

Parallel processing streams. In the primate, the segregation of cortical compartments into $\mathrm{CO}$ blobs and interblobs has been functionally related to the hierarchical processing of color and 
form perception, which are, furthermore, related to similarly segregated geniculocortical pathways (Hubel and Livingstone, 1987; Livingstone and Hubel, 1987a, b; but see Condo and Casagrande, 1990). The lateral geniculate innervation of cat visual cortex arises from three major classes of neurons $(\mathrm{X}-, \mathrm{Y}-$, and W-cells), which also form functionally, and anatomically separable processing streams (for review, see Sherman, 1985). The differential distributions of $5-\mathrm{HT}_{\mathrm{IC}}$ receptors appear to mirror the X-cell innervation of visual cortex, while the $5-\mathrm{HT}_{2}$ distribution appears to reflect non-X-cell geniculocortical projections. Like the peak distributions of $5-\mathrm{HT}_{1 \mathrm{C}}$ receptors, terminals of all $\mathrm{X}$-cell axons are restricted to area 17 , predominantly within deeper levels of layer IV, but with lesser projections to lower layer III and layer V (Ferster and LeVay, 1978; Humphrey et al., 1985). Areas 18,19, and LS, which reccive no X-cell input, also do not contain high levels of ${ }^{3} \mathrm{H}$-mesulergine binding. Similar to the distribution of $5-\mathrm{HT}_{2}$ receptors, $\mathrm{Y} / \mathrm{W}$-cell projections arborize within upper levels of layer IV and lower layer III of areas 17 and 18 (Humphrey et al., 1985). Finally, high levels of 5-HT $\mathrm{HT}_{2}$, but not $5-\mathrm{HT}_{1 \mathrm{C}}$, receptors transiently demarcate LS, which receives input from several classes of $Y$-cells but not from $\mathrm{X}$-cells (Berson, 1985) and only a transient, sparse innervation from cells in the A laminae (Tong et al., 1991). Furthermore, the development of visual response properties of suprasylvian cortex develop between PD9 and PD15 (McCall et al., 1988; Price et al., 1988), an age when $5-\mathrm{HT}_{2}$ receptors exhibit a striking increase in their levels of expression.

Intracortical projections. Corticortical connections among pyramidal neurons in layers II/III and $\mathrm{V}$ in the visual cortex of primates and nonprimates are periodically distributed at $1 \mathrm{~mm}$ intervals in the tangential plane (sce Katz and Callaway, 1992, for review). When related to $\mathrm{CO}$ blobs in primate visual cortex, intrinsic cortical connections appear to be made reciprocally among $\mathrm{CO}$-rich patches or $\mathrm{CO}$-poor regions, but not between them (Livingstone and Hubel, 1984b). Preliminary studies indicate that this relationship among $\mathrm{CO}$ blobs holds true for intracortical connections in cat striate cortex as well (Boyd and Matsubara, 1992). This patchy pattern of intrinsic connections emerges early in development from an immature, homogeneous distribution (Luhmann et al., 1986; Price, 1986; Callaway and Katz, 1990), by a process of axon elimination, which is activity dependent (Callaway and Katz, 1991; Löwel and Singer, 1992). Based on the interrelationship between the patchy distribution of 5-HT receptors and $\mathrm{CO}$ blobs in cat cortex, it is possible that the transient columnar distribution of 5-HT receptors is related to the process of refining cortical interconnections during development. This is substantiated by the observation that the critical period for the refinement of corticocortical projections ends by 14 weeks (Dalva et al., 1992), at the same time that 5-HT receptor patches disappear.

\section{Comparative studies}

5-HT, receptors. Among the numerous 5-HT receptor subtypes, the $5-\mathrm{HT}_{1 \mathrm{~A}}$ subtype has been the most intensively studied, primarily as a result of the development of the highly selective radioligand ${ }^{3} \mathrm{H}-8-\mathrm{OH}-\mathrm{DPAT}$ (Gozlan et al., 1983). Its specificity has been demonstrated to be identical in the neocortex of species as diverse as rat, pig, and human (Hoyer et al., 1985, 1986a). Using ${ }^{3} \mathrm{H}-8-\mathrm{OH}-\mathrm{DPAT}$ we have shown that $5-\mathrm{HT}_{1 \mathrm{~A}}$ receptor sites are highly regulated in the cat visual cortex during development. Consistent with our results, levels of $5-\mathrm{HT}_{1 \mathrm{~A}}$ receptors in the cortex of developing rats (Daval et al., 1987) and humans
(Bar-Peled et al., 1991) exhibit transient, three- to fourfold higher densities than in the adult. In the rat, levels increased markedly during the first 3 weeks after birth, compared to the cat visual cortex, where the highest levels of 5-HT $\mathrm{HA}_{1 \mathrm{~A}}$ receptors were demonstrated between 2 and 5 weeks postnatally. In human brain, the highest densities of $5-\mathrm{HT}_{1 \mathrm{~A}}$ receptors were found in the fetal neocortex, between the 16 th and 22 nd weeks of gestation (Bar-Peled et al., 1991). Unlike the rat, where levels remain essentially stable through the remainder of the animals' lifespan (Daval et al., 1987; Gozlan et al., 1990), our observations of a progressive reduction of ${ }^{3} \mathrm{H}-8-\mathrm{OH}-\mathrm{DPAT}$ binding density are consistent with results obtained in the aging human cortex (Middlemiss et al., 1986; Cross et al., 1988; Dillon et al., 1991).

The ontogenetic expression of 5-HT receptors in cat visual cortex, analyzed with ${ }^{3} \mathrm{H}-5-\mathrm{HT}$, is virtually identical to that of $5-\mathrm{HT}_{1 \wedge}$ receptors, suggesting that the $5-\mathrm{HT}_{1 \mathrm{~A}}$ subtype may be the predominant subtype of the $5-\mathrm{HT}_{1}$ family found in cat visual cortex. During postnatal development of the kitten visual cortex, levels of ${ }^{3} \mathrm{H}-5-\mathrm{HT}$ binding in tissue homogenates increased from low levels at birth, to a peak at 4 weeks of age, and then subsequently declined to adult levels (Jonsson and Kasamatsu, 1983). In rat visual cortex, by contrast, the transient increase of ${ }^{3} \mathrm{H}-5$ HT binding was apparent during the first postnatal week followed by a progressive decline with increasing age (Uzbekov et al., 1979; Zifa et al., 1988; but see Uphouse and Bondy, 1981; Zilles et al., 1985). Although providing circumstantial support, the usefulness of ${ }^{3} \mathrm{H}-5-\mathrm{HT}$ in studies of 5-HT receptor subtypes is obviously constrained by its demonstrated lack of specificity.

The temporal and laminar patterns of the distribution of $5-\mathrm{HT}_{\mathrm{IA}}$ receptors did not vary significantly between the different visual cortical regions examined. Except for the early postnatal period, 5-HT $\mathrm{HA}_{1 \mathrm{~A}}$ receptors were highest in supragranular cortical layers and lowest in middle layers, and attained intermediate levels in infragranular layers. Comparable laminar and ontogenetic analyses of the distribution of $5-\mathrm{HT}_{\mathrm{IA}}$ receptors in visual cortex of other species have not yet been reported. Unlike the cat, the highest levels of ${ }^{3} \mathrm{H}-8-\mathrm{OH}-\mathrm{DPAT}$ binding in the rat are localized to deeper cortical layers (Marcinkiewicz et al., 1984; Pazos and Palacios, 1985). On the other hand, the laminar pattern of 5-HT $\mathrm{HA}_{\mathrm{A}}$ receptors among nonstriate neocortical regions appears similar between adult cat and humans, but a detailed description of human visual cortex findings was not presented (Dillon et al., 1991; Pazos et al., 1987a, 1991). The laminar pattern of $5-\mathrm{HI}_{1 \mathrm{~A}}$ receptors, which differentiates striate from the immediately adjacent, extrastriate visual cortical areas in the adult macaque, appcars identical to the results presented here (Parkinson et al., 1989). In the cat, this distinct pattern develops between PD120 and adulthood as a result of a laminarand region-specific reduction in ${ }^{3} \mathrm{H}-8-\mathrm{OH}-\mathrm{DPAT}$ binding. Developmental studies in the striate cortex of primates are required to evaluate possible ontogenetic similarities between these species.

The resolution of in vitro autoradiography is not sufficient to visualize the cell bodies of neurons or to determine the subcellular localization of receptors. However, indirect evidence provided by neuron-specific lesions indicates that the $5-\mathrm{HT}_{\mathrm{IA}}$ receptors are localized entirely on neurons intrinsic to the kitten visual cortex (R. H. Dyck and M. S. Cynader, unpublished observations). The regional colocalizations of 5-HT AA $_{\text {mRA, }}$ assessed with in situ hybridization, combined with in vitro autoradiography, in the adult rat brain, support the idea that $5-\mathrm{HT}_{1 \mathrm{~A}}$ 
receptors have a predominantly somatodendritic location (Chalmers and Watson, 1991; Pompeiano et al., 1992).

$5-H T_{2}$ receptors. The mature distributions of $5-\mathrm{HT}_{1 \mathrm{C}}$ and $5-\mathrm{HT}_{2}$ receptor subtypes have been extensively studied in the rodent, porcine, and primate brain (Pazos et al., 1984a, 1985, 1987a,b, 1991; Pazos and Palacios, 1985; Hoyer et al., 1986b; Blue et al., 1988; Rakic et al., 1988; Lidow et al., 1989; McKenna et al., 1989; Gross-Isseroff et al., 1990). Consistent with the results presented here, $5-\mathrm{HT}_{1 \mathrm{C}}$ binding sites were reported to be present at low levels, with a slight preference in the middle layers reported in the adult human and rat occipital cortex (Pazos and Palacios, 1985; Hoyer et al., 1986b; Pazos et al., 1987a, 1991). The localization of mRNA encoding the $5-\mathrm{HT}_{\mathrm{IC}}$ receptor in adult rodents has confirmed and extended these results (Hoffman and Mezey, 1989; Molineaux et al., 1989; Mengod et al., 1990a).

Possibly due to the greater availability of $5-\mathrm{HT}_{2}-$ specific ligands, the distribution of $5-\mathrm{HT}_{2}$ receptors has been more extensively studied, particularly in striate cortex. In adult cats, we found that the highest densities of $5-\mathrm{HT}_{2}$ sites are equally distributed across layers I-IV in striate cortex, and predominantly in superficial layers in extrastriate regions. In rats, the highest concentration of $5-\mathrm{HT}_{2}$ receptors was demonstrated in the middle cortical layers (III, IV, and V), with highest concentrations at the layer IV/V border (Pazos et al., 1985; Blue et al., 1988; Mengod et al., 1990b). In human and primate material, there are concentrations in layers III, IVa, and IVc (Pazos et al., 1987b, 1991; Rakic et al., 1988; Lidow et al., 1989; Parkinson et al., 1989; Gross-Isseroff et al., 1990). It is possible that these inconsistencies can be attributed to species-specific localization patterns. Alternatively, the majority of these studies used $5-\mathrm{HT}_{2}$ antagonists (e.g., ${ }^{3} \mathrm{H}$-ketanserin, ${ }^{125} \mathrm{I}$-LSD), which have been shown to label more than one population of $5-\mathrm{HT}_{2}$ receptors (McKenna and Peroutka, 1989; Pierce and Peroutka, 1989) and/ or differential affinity states of multiple receptor subtypes (Lyon et al., 1987; Leonhardt and Titeler, 1989).

Very little is known of the ontogenesis of $5-\mathrm{HT}_{2}$ receptor family in other species or cortical areas. In this report we have demonstrated that the distributions, and levels, of $5-\mathrm{HT}_{1 \mathrm{C}}$ and $5-\mathrm{HT}_{2}$ receptors are robustly regulated in the kitten visual cortex during postnatal development. The ontogenetic regulation of $5-\mathrm{HT}_{1 \mathrm{C}}$ and $5-\mathrm{HT}_{2}$ receptors has also been studied in rat and human brain, but has not been determined with regional specificity. In the whole rat brain, Roth and coworkers have reported that transient increases in 5-HT $1 \mathrm{C}$ and 5- $\mathrm{HT}_{2}$ sites during early development (Roth et al., $1991 \mathrm{~b}$ ) were accompanied by parallel increases in the corresponding mRNA (Roth et al., 1991a) that became markedly reduced with age. A marked reduction of $5-\mathrm{HT}_{2}$ receptors in aged rats has also been reported by others (Battaglia et al., 1988; Gozlan et al., 1990). In addition, although studies of early development have not been reported, age-dependent reductions of $5-\mathrm{HT}_{2}$ receptors have been reported to occur in the human brain, beyond adolescence, during normal aging and in age-related disease (Marcusson et al., 1984; Reynolds et al., 1984; Wong et al., 1984; Cross et al., 1988; GrossIsseroff et al., 1990; Biegon, 1991).

The cellular localization of $5-\mathrm{HT}_{1 \mathrm{C}}$ and $5-\mathrm{HT}_{2}$ receptors in the adult rodent brain has been inferred, using in situ hybridization and lesion studies, to reside predominantly on nonserotonergic neurons that are intrinsic to the neocortex (Fischette et al., 1987; Hoffman and Mezey, 1989; Molineaux et al., 1989; Mengod et al., 1990a,b). However, based on lesion studies, and the effects of input manipulations reported previously (Dyck et al., 1991), it would appear that, at least during a distinct phase of postnatal development, $5-\mathrm{HT}_{1 \mathrm{C}}$ receptors are associated with axonal terminals of lateral geniculate neurons or possibly with glial cells. In addition, the transient, high levels of $5-\mathrm{HT}_{2}$ receptors distributed within the subcortical white matter suggest that a significant proportion of these binding sites are localized to glial cells. The resolution of the autoradiographic technique is not sufficiently fine to determine this with certainty. A detailed analysis of these receptors using techniques providing cellular resolution are necessary.

As in other species (Pazos et al., 1984b; Yagaloff and Hartig, 1985; Hoyer et al., 1986b; Zilles et al., 1986), we also found very high concentrations of ${ }^{3} \mathrm{H}$-mesulergine binding sites in the choroid plexus at all stages of development. Our results also indicate high levels of ${ }^{125} \mathrm{I}$-DOI binding in the choroid plexus of the cat brain (see Fig. 11), which are consistent with previous findings (McKenna et al., 1989).

$5-\mathrm{HT}_{3}$ receptors. As mentioned in the Results, the presence of $5-\mathrm{HT}_{3}$ receptors in the developing kitten visual cortex was not detected using currently available tritiated ligands. Consistent with binding studies in other species (Kilpatrick et al., 1988; Kilpatrick et al., 1989; Waeber et al., 1989; Barnes et al., 1992), we did find dense labeling in limbic structures, indicating that the lack of binding in visual cortical areas was not due to lack of sensitivity, or other methodological issues. The development of radioligands with higher specific activity may help to allow autoradiographic localization of the low levels of $5-\mathrm{HT}_{3}$ sites that the cortex may yet possess.

5-HT uptake. A robust developmental regulation of 5- $\mathrm{HT}_{\mathrm{Up}}$ sites has been previously described for the rat visual and somatosensory cortex (D'Amato et al., 1987). We also found that $5-\mathrm{HT}_{\mathrm{U}}$ sites were developmentally regulated in the postnatal kitten visual cortex. Unlike the kitten, where we observe a gradual increase in expression until adulthood, which is essentially homogeneous across cortical laminae, $5-\mathrm{HT}_{\mathrm{Up}}$ sites in the developing rat are transiently expressed, during the early postnatal period, at very high levels within layer IV in primary sensory areas (D'Amato et al., 1987). These $5-\mathrm{HT}_{\mathrm{Up}}$ sites are presumably localized on axon terminals of serotonergic neurons that arise from the raphe nuclei (D'Amato et al., 1987; Bennett-Clarke et al., 1991). Apart from the apparent lack of a transient increase in expression during early development, our descriptions of the regional and laminar distributions of $5-\mathrm{HT}_{\mathrm{Up}}$ sites in the adult cat are consistent with those found in human (Duncan et al., 1992), primate (Lidow et al., 1989), and rat (Kovachich et al., 1988; Duncan et al., 1992) visual cortices. In each of these studies, the distribution of high-affinity $5-\mathrm{HT}_{\mathrm{Up}}$ sites was correlated with the density of serotonergic innervation. The relationship of 5-HT receptor subtypes to serotonergic innervation of visual cortex is discussed in greater detail below.

\section{Relationship to serotonergic innervation}

Although the ontogeny of the serotonergic innervation of visual cortex has been investigated in rats (Descarries et al., 1975; Lidov et al., 1980; D'Amato et al., 1987; Papadopoulos et al., 1987; Bennett-Clarke et al., 1991; Nakazawa et al., 1992), ferrets (Voigt and De Lima, $1991 \mathrm{a}, \mathrm{b}$ ), cats (Mulligan and Törk, 1988; Gu et al., 1990), and primates (Morrison et al., 1982, 1984; Foote and Morrison, 1984; Kosofsky et al., 1984; de Lima et al., 1988), corresponding data regarding 5-HT receptors during early postnatal development are only available for the rat. 
In the rat, a transient hyperinnervation of primary sensory areas by raphe neurons (D'Amato et al., 1987; Bennett-Clarke et al., 1991; Nakazawa et al., 1992) is accompanied by corresponding levels of 5-HT $\mathrm{Up}_{\mathrm{p}}$ sites (D'Amato et al., 1987) and 5-HT ${ }_{1 \mathrm{~B}}$ receptors (Leslie et al., 1992). Somewhat similar to the rat, the expression of $5-\mathrm{HT}_{\mathrm{Up}}$ sites in kitten visual cortex appears to be loosely correlated with its serotonergic innervation. In the second postnatal week (the earliest age studied), 5-HT-immunoreactive fibers were equally and sparsely distributed across cortical laminae I-V (Gu et al., 1990), but by postnatal week 6 appeared adult-like, with fiber densities greatest in superficial laminae, less dense in lamina V, and sparse in laminae IV and VI (Mulligan and Törk, 1988; Gu et al., 1990). Among the different 5-HT receptor subtypes investigated, the laminar distribution of $5-\mathrm{HT}_{\mathrm{AA}}$ receptors in the cat visual cortex most closely resembled the pattern of its serotonergic innervation. Although their spatial distributions through postnatal development were similar, the marked increases of $5-\mathrm{HT}_{\mathrm{IA}}$ receptors between PD20 and PD40, followed by a reduction to adult levels, do not appear to be reflected by a corresponding change in fiber density ( $\mathrm{Gu}$ et al., 1990). Biochemical analyses indicate a marked increase in the endogenous concentrations of 5-HT in the developing kitten visual cortex between the third and fifth postnatal weeks (Jonsson and Kasamatsu, 1983), with a parallel transient increase throughout the brain (Daszuta et al., 1979), which is identical to the autoradiographic data, but in conflict with the available immunocytochemical results ( $\mathrm{Gu}$ et al., 1990). Furthermore, the ontogenesis of serotonergic fibers in the ferret, a related carnivore whose cortical histogenesis is nearly identical to that of the cat, demonstrates an increased density of serotonergic fibers during the equivalent postnatal period (Voigt and De Lima, 1991b). These results suggest that this period of postnatal development is potentially critical for the phenotypic maturation of serotonergic neurons.

The relationship between 5-HT receptors, and particularly the 5-HT ${ }_{1 \mathrm{~A}}$ subtype, with the serotonergic innervation of visual cortex appears more clearly defined in the adult cat. Immunocytochemical studies in the adult cat indicate that the arbors of serotonergic axon terminals are mostly restricted to the superficial laminae (I-III) and layer V (Mulligan and Törk, 1988; Gu et al., 1990). The predominantly superficial distribution of fibers is consistent with the highest levels of the $5-\mathrm{HT}_{1 \mathrm{~A}}, 5-\mathrm{HT}_{2}$, and $5-\mathrm{HT}_{\mathrm{Up}}$, but only the $5-\mathrm{HT}_{1 \mathrm{~A}}$ receptor exhibits a higher level of expression specific to layer $\mathrm{V}$. Although not reported in these studies, it would be interesting to see whether the decreased density of $5-\mathrm{HT}_{1 \mathrm{~A}}$ receptors in areas 17 and 18 , relative to the directly adjacent cortical regions, is reflected by a similarly sharp transition in the density of innervation by serotonergic fibers.

The serotonergic innervation of the mammalian visual cortex arrives via two parallel ascending projections, which are morphologically distinct, and originate from neurons in either the dorsal or median raphe nuclei (Moliver, 1987; Mulligan and Törk, 1988). Their differential distributions and their relative contribution to the innervation of the visual cortex of cats during development are not known, which precludes an analysis of their relative distribution to that of 5-HT receptor subtypes. However, the laminar pattern of 5- $\mathrm{HT}_{2}$ receptors in the neocortex of rats has been described to be associated with the fine axon projection that arises from the dorsal raphe nucleus (Blue et al., 1988). Similarly, 5-HT axons (Morrison et al., 1982; Kosofsky and Molliver, 1987) and synapses (de Lima et al., 1988) in primate striate cortex are present in all cortical layers but form especially prominent, dense bands of arborizing fibers from midlayer III through IVC $\alpha$ (Morrison et al., 1982; Morrison and Foote, 1986; Kosofsky and Molliver, 1987), which is reflected by the distribution of 5-HT 2 receptors (Rakic et al., 1988; Lidow et al., 1989; Parkinson et al., 1989). However, without the development of a method with improved cellular resolution, which is compatible with double label studies (e.g., 5-HT receptorspecific antibodies), this relationship cannot be ascertained, or extended to studies in the cat.

The data presented here indicate that the regulation of serotonergic innervation and $5-\mathrm{HT}$ receptors are independently controlled during cortical development. Furthermore, the existence of two pharmacologically and anatomically separate ascending serotonergic systems, combined with a multiplicity of receptors to activate, provides a diverse range of responses that may be necessary to guide the multiple processes involved in visual cortical development.

\section{Conclusions}

In the present study we have described the comparative distributions of the 5-HT $1 \mathrm{~A}, 1 \mathrm{C}, 2$, and 3 receptor subtypes, as well as the 5-HT uptake site, in the kitten visual cortex during postnatal development. The temporal and spatial complementarity of their respective distributions indicate that $5-\mathrm{HT}$ might play multiple roles in different visual cortical regions and layers at different times during development. Furthermore, this first demonstration that specific 5-HT receptors are transiently organized in columns of kitten visual cortex argues for a specific role for 5-HT to participate in processes that determine the synaptic development and functional organization of columnar systems in visual cortex. Investigations of the physiological consequences of activating specific 5-HT receptor subtypes in the visual cortex during postnatal development, together with anatomical studies to determine their precise cytological localization, are underway to address fully this role for 5-HT.

\section{References}

Anderson PA, Olavarria J, Van Sluyters RC (1988) The overall pattern of ocular dominance bands in cat visual cortex. J Neurosci 8:21832200.

Bar-Peled O, Gross-Isseroff R, Ben-Hur H, Hoskins I, Groner Y, Biegon $\Lambda$ (1991) Fetal human brain exhibits a prenatal peak in the density of serotonin 5-HT1A receptors. Neurosci Lett 127:173-176.

Barnes JM, Barnes NM, Costall B, Jagger SM, Naylor RJ, Robertson DW, Roe SY (1992) Agonist interactions with 5-HT3 receptor recognition sites in the rat entorhinal cortex labeled by structurally diverse radioligands. Br J Pharmacol 105:500-504.

Battaglia $G$, Norman AB, Creese I (1988) Differential serotonin-2 receptor recovery in mature and senescent rat brain after irreversible receptor modification: effect of chronic reserpine treatment. J Pharmacol Exp Ther 243:69-75.

Bear MF, Singer W (1986) Modulation of visual cortical plasticity by acetylcholine and noradrenaline. Nature 320:172-176.

Bear MF, Carnes KM, Ebner FF (1985) Postnatal changes in the distribution of acetylcholinesterase in kitten striate cortex. J Comp Neurol 237:519-532.

Beaulieu C, Dyck R, Cynader M (1992) Enrichment of glutamate in zinc-containing terminals of the cat visual cortex. Neuroreport 3:861864.

Bennett-Clarke CA, Chiaia NL, Crissman RS, Rhoades RW (1991) The source of the transient serotoninergic input to the developing visual and somatosensory cortices in the rat. Neuroscience 43:163183.

Berson DM (1985) Cat lateral suprasylvian cortex: Y-cell inputs and corticotectal projection. J Neurophysiol 53:544-556.

Biegon A (1991) Acetylcholine, serotonin, and $\beta$ adrenoceptors. In: 
Receptors in the human nervous system (Mendelsohn FAO, Paxinos G, eds), pp 49-69. San Diego: Academic.

Blasdel GG (1992) Differential imaging of ocular dominance and orientation selectivity in monkey striate cortex. J Neurosci 12:31153138.

Blasdel GG, Salama G (1986) Voltage-sensitive dyes reveal a modular organization in monkey striate cortex. Nature 321:579-585.

Blue ME, Yagaloff KA, Mamounas LA, Hartig PR, Molliver ME (1988) Correspondence between 5-HT2 receptors and serotonergic axons in rat neocortex. Brain Res 453:1-7.

Bode-Greuel KM, Singer W (1989) The development of $N$-methylD-aspartate receptors in cat visual cortex. Dev Brain Res 46:197-204.

Bonhoeffer T, Grinvald A (1991) Iso-orientation domains in cat visual cortex are arranged in pinwheel-like patterns. Nature 353:429-431.

Boyd JD, Matsubara JA (1992) Segregated processing streams in cat visual cortex? Relationship of patchy connectivity to an extrastriate area, cytochrome oxidase staining, and local connections. Soc Neurosci Abstr 18:298.

Callaway EM, Katz LC (1990) Emergence and refinement of clustered horizontal connections in cat striate cortex. J Neurosci 10:1134-1153.

Callaway EM, Katz LC (1991) Effects of binocular deprivation on the development of clustered horizontal connections in cat striate cortex. Proc Natl Acad Sci USA 88:745-749.

Chalmers DT, Watson SJ (1991) Comparative anatomical distribution of 5-HT1A receptor mRNA and 5-HT1A binding in rat brain-a combined in situ hybridization/in vitro receptor autoradiographic study Brain Res 561:51-60.

Closse A (1983) [ $\left.{ }^{3} \mathrm{H}\right]-$ mesulergine; a selective ligand for serotonin S2 receptors. Life Sci 32:2485-2495.

Condo GJ, Casagrande VA (1990) Organization of cytochrome oxidase staining in the visual cortex of nocturnal primates (Galago crassicaudatus and Galago senegalensis). I. Adult patterns. J Comp Neurol 293:632-645.

Cresho HS, Rasco LM, Rose GH, Condo GJ (1992) Blob-like pattern of cytochrome oxidase staining in ferret visual cortex. Soc Neurosci Abstr 18:298.

Cross AJ, Slater P, Perry EK, Perry RH (1988) An autoradiographic analysis of serotonin receptors in human temporal cortex: changes in Alzheimer-type dementia. Neurochem Int 13:89-96.

Cynader M, Timney BN, Mitchell DE (1980) Period of susceptibility of kitten visual cortex to the effects of monocular deprivation extends beyond six months of age. Brain Res 191:545-550.

Cynader M, Shaw C, van Huizen F, Prusky G (1990) Transient receptor expression in visual cortex development and the mechanisms of cortical plasticity. In: The neocortex (Finlay BL, ed), pp 245-253. New York: Plenum.

Cynader M, Shaw C, van Huizen F, Prusky G (1991) Redistribution of neurotransmitter receptors and the mechanism of cortical developmental plasticity. In: Development of the visual system (Lam DM, Shatz C, eds), pp 33-42. Cambridge, MA: MIT Press.

Dalva EM, Callaway EM, Katz LC (1992) A critical period for the development of clustered horizontal connections in cat striate cortex. Soc Neurosci Abstr 18:1455.

D'Amato R J, Blue ME, Largent BL, Lynch DR, Ledbetter DJ, Molliver ME, Snyder SH (1987) Ontogeny of the serotonergic projection to rat neocortex: transient expression of a dense innervation to primary sensory areas. Proc Natl Acad Sci USA 84:4322-4326.

Daszuta A, Gaudin-Chazal G, Fandon M, Barrit MC, Lernaux JP (1979) Endogenous levels of tryptophan, serotonin and 5 -hydroxyindole acetic acid in the developing brain of the cat. Neurosci Lett 11:187-192.

Daval G, Verge D, Becerril A (1987) Transient expression of 5-HT receptor binding sites in somc areas of the rat CNS during postnatal development. Int J Dev Neurosci 5:171-180.

Daw NW (1973) Neurophysiology of color vision. J Physiol (Lond) 211:567-592.

de Lima A, Bloom FE, Morrison JH (1988) Synaptic organization of serotonin-immunoreactive fibers in primary visual cortex of the macaque monkey. J Comp Neurol 274:280-294.

Derkach V, Surprenant A, North RA (1989) 5-HT3 receptors are membrane ion channels. Nature 339:706-709.

Descarries L, Beaudet A, Watkins KC (1975) Serotinin nerve terminals in adult rat neocortex. Brain Res 100:563-588.

Dillon KA, Gross-Isseroff R, Israeli M, Biegon A (1991) Autoradiographic analysis of serotonin 5-HT1A receptor binding in the human brain postmortem: effects of age and alcohol. Brain Res 554:56-64.
Duncan GE, Little KY, Kirkman JA, Kaldas RS, Stumpf WE, Breese GR (1992) Autoradiographic characterization of ${ }^{3} \mathrm{H}$-imipramine and ${ }^{3} \mathrm{H}$-citalopram binding in rat and human brain: species differences and relationships to serotonin innervation patterns. Brain Res 591: 181-197.

Dyck RH, Cynader MS (1989) Ontogeny of the laminar distribution of zinc in the cat visual cortex. Soc Neurosci Abstr 15:1336.

Dyck RH, Cynader MS (1990a) Serotonin receptors exhibit transient laminar and columnar distributions in postnatal cat visual cortex. Soc Neurosci Abstr 16:987.

Dyck RH, Cynader MS (1990b) Transient laminar and columnar expression of serotonin receptors in the developing cat visual cortex. $\mathrm{J}$ Cell Biochem 14F:43.

Dyck RH, Cynader MS (1993) An interdigitated columnar mosaic of cytochrome oxidase, zinc, and neurotransmitter-related molecules in cat and monkey. Proc Natl Acad Sci USA, in press.

Dyck R, Cynader M (1992) Enzymes, ions and receptors distinguish novel, complementary columnar systems in developing cat visual cortex. Soc Neurosci Abstr 18:1308.

Dyck R, Lepore F, Cynader M (1991) The transient columnar expression of serotonin $1 \mathrm{C}$ receptors is dependent upon normal binocular interaction. Soc Neurosci Abstr 17:900.

Dyck R, Beaulieu C, Cynader M (1993a) Histochemical localization of synaptic zinc in the developing cat visual cortex. J Comp Neurol 329:53-67.

Dyck RH, Chaudhuri A, Cynader MS (1993b) A conserved columnar architecture in striate cortex of cats and primates formed by an interdigitated mosaic of synaptic zinc and cytochrome oxidase. Invest Ophthalmol Vis Sci 34:1173.

Ferster D, LeVay S (1978) The axonal arborizations of lateral geniculate neurons in the striate cortex of the cat. J Comp Neurol 182 923-944.

Fischette CT, Nock B, Renner K (1987) Effects of 5,7-dihydroxytryptamine on serotonin-1 and serotonin-2 receptors throughout the rat central nervous system using quantitative autoradiography. Brain Res 421:263-279.

Foote SL, Morrison JH (1984) Postnatal development of laminar innervation patterns by monoaminergic fibers in monkey (Macaca fascicularis) primary visual cortex. J Neurosci 4:2667-2680

Fox K, Daw NW, Sato H, Czepita D (1990) Dark-rearing delays the loss of NMDA-function in kitten visual cortex. Nature 350:342-344.

Glennon RA, Raghupathi R, Bartyzel P, Titeler M, Leohnardt S (1992) Binding of phenylalkylamine derivatives at 5-HT1C and 5-HT2 serotonin receptors: evidence for a lack of selectivity. J Med Chem 35: 734-740.

Gozlan H, Mestikawy SF, Pichat I , (1983) Identification of presynaptic serotonin autoreceptors using a new ligand: ${ }^{3} \mathrm{H}-\mathrm{PAT}$. Nature 305: 140-142.

Gozlan H, Daval G, Verge D, Spampinato U, Fattaccini CM, Gallissot MC, El MS, Hamon M (1990) Aging associated changes in serotonergic and dopaminergic pre- and postsynaptic neurochemical markers in the rat brain. Neurobiol Aging 11:437-449.

Gross-Isseroff R, Salama D, Israeli M, Biegon A (1990) Autoradiographic analysis of age-dependent changes in serotonin 5-HT2 receptors of the human brain postmortem. Brain Res 519:223-227.

$\mathrm{Gu}$ Q, Singer W (1991) Involvement of serotonin in neuronal plasticity of kitten visual cortex. IBRO Abstr 3:314.

Gu Q, Patel B, Singer W (1990) The laminar distribution and postnatal development of serotonin-immunoreactive axons in the cat primary visual cortex. Exp Brain Res 81:257-266.

Hartig PR (1989) Molecular biology of 5-HT receptors. Trends Pharmacol Sci 10:64-69.

Hartig P, Kao HT, Macchi M, Adham N, Zgombick J, Weinshank R, Branchek T (1990) The molecular biology of serotonin receptors: an overview. Neuropsychopharmacology 3:335-347.

Hendrickson AE (1985) Dots, stripes and columns in monkey visual cortex. Trends Neurosci 8:406-410.

Heuring RE, Peroutka SJ (1987) Characterization of a novel ${ }^{3} \mathrm{H}-5$ hydroxytryptamine binding site subtype in bovine brain membranes. J Neurosci 7:894-903.

Hoffman BJ, Mezey E (1989) Distribution of serotonin 5-HTIC receptor mRNA in adult rat brain. FEBS Lett 247:453-462.

Hoyer D (1988) Molecular pharmacology and biology of 5-HT1C receptors. Trends Pharmacol Sci 9:89-94.

Hoyer D, Engel G, Kalkman HO (1985) Molecular pharmacology of 5-HT-1 and 5-HT-2 recognition sites in rat and pig brain membranes: 
radioligand binding studics with $\left[{ }^{3} \mathrm{H}\right] 5-\mathrm{HT},\left[{ }^{3} \mathrm{H}\right] 8-\mathrm{OH}-\mathrm{DPAT}$, $(-)\left[{ }^{125} \mathrm{I}\right]$ iodocyanopindolol, $\left[{ }^{3} \mathrm{H}\right]$ mesulergine and $\left[{ }^{3} \mathrm{H}\right]$ ketanserin. Eur J Pharmacol 118:1-2.

Hoyer D, Pazos A, Probst A, Palacios JM (1986a) Serotonin receptors in the human brain. I. Characterization and autoradiographic localization of 5-HT $1 \mathrm{~A}$ recognition sites. Apparent absence of 5-HT ${ }_{1 \mathrm{~B}}$ recognition sites. Brain Res 376:85-96.

Hoyer D, Pazos A, Probst A, Palacios JM (1986b) Serotonin receptors in the human brain. II. Characterization and autoradiographic localization of 5- $\mathrm{HT}_{1 \mathrm{C}}$ and 5- $\mathrm{HT}_{2}$ recognition sites. Brain Res 376:97107.

Hubel DH, Livingstone MS (1987) Segregation of form, color, and stereopsis in primate area 18. J Neurosci 7:3378-3415.

Hubel DH, Wiesel TN (1962) Receptive fields, binocular interaction and functional architecture in the cat's visual cortcx. J Physiol (Lond) 160:106-154.

Humphrey AL, Sur M, Uhlrich DJ, Sherman SM (1985) Projection patterns of individual $\mathrm{X}$ - and $\mathrm{Y}$-cell axons from the lateral geniculate nucleus to cortical area 17 in the cat. J Comp Neurol 233:159-189.

Jones KR, Spear PD, Tong L (1984) Critical periods for effects of monocular deprivation: differences between striate and extrastriate cortex. J Neurosci 4:2543-2552.

Jonsson G, Kasamatsu T (1983) Maturation of monoamine neurotransmitters and receptors in cat occipital cortex during postnatal critical period. Exp Brain Res 50:449-458.

Kasamatsu T, Shirokawa T (1985) Involvement of beta-adrenoreceptors in the shift of ocular dominance after monocular deprivation. Exp Brain Res 59:507-514.

Kasamatsu T, Pettigrew JD, Ary M (1979) Restoration of visual cortical plasticity by local microperfusion of norepinephrine. J Comp Neurol 185:163-182.

Katz LC, Callaway EM (1992) Development of local circuits in mammalian visual cortex. Annu Rev Neurosci 15:31-56.

Kilpatrick GJ, Jones BJ, Tyers MB (1987) Identification and distribution of 5-HT3 receptors in rat brain using radioligand binding. Nature 330:746-748.

Kilpatrick GJ, Jones BJ, Tyers MB (1988) The distribution of specific binding of the 5-HT3 receptor ligand $\left[{ }^{3} \mathrm{H}\right] \mathrm{GR} 65630$ in rat brain using quantitative autoradiography. Neurosci Lett 94:1-2.

Kilpatrick GJ, Jones BJ, Tyers MB (1989) Binding of the 5-HT3 ligand, $\left[{ }^{3} \mathrm{H}\right] \mathrm{GR} 65630$, to rat area postrema, vagus nerve and the brains of several species. Eur J Pharmacol 159:157-164.

Kleinschmidt A, Bear MF, Singer W (1987) Blockade of "NMDA" receptors disrupts experience-dependent plasticity of kitten striate cortex. Science 238:355-358.

Kosofsky BE, Molliver ME (1987) The serotoninergic innervation of cerebral cortex: different classes of axon terminals arise from dorsal and median raphe nuclei. Synapse 1:153-168.

Kosofsky BE, Molliver ME, Morrison JH, Foote SL (1984) The serotonin and norepinephrine innervation of primary visual cortex in the cynomolgus monkey (Macaca fascicularis). I Comp Neurol 230 $168-178$.

Kovachich GB, Aronson CE, Brunswick DJ, Frazer A (1988) Quantitative autoradiography of serotonin uptake sites in rat brain using $\left[{ }^{3} \mathrm{H}\right]$ cyanoimipramine. Brain Res 454:78-88.

Leonhardt S, Titeler M (1989) Serotonin 5-HT2 receptors: two states versus two subtypes. J Neurochem 53:316-318.

Leonhardt S, Herrick-Davis K, Titeler M (1989) Detection of a novel serotonin receptor subtype (5-HT1E) in human brain: interaction with a GTP-binding protein. J Neurochem 53:465-471.

Leslie MJ, Bennett-Clarke CA, Rhoades RW (1992) Serotonin-1B receptors form a transient vibrissa-related pattern in the primary somatosensory cortex of the developing rat. Dev Brain Res 69:143148 .

LeVay S, Nelson SB (1991) Columnar organization of the visual cortex. In: The neural basis of visual function (Leventhal AG, ed), pp 266-315. London: Macmillan.

LeVay S, Stryker MP, Shatz CJ (1978) Ocular dominance columns and their development in layer IV of the cat's visual cortex: a quantitative study. J Comp Neurol 179:223-244.

Lidov HGW, Grzanna R, Molliver ME (1980) The serotonin innervation of the cerebral cortex in rat: an immunohistochemical analysis. Neuroscience 5:207-227.

Lidow MS, Goldman-Rakic PS, Gallager DW, Rakic P (1989) Quantitative autoradiographic mapping of serotonin $5-\mathrm{HT} 1$ and $5-\mathrm{HT} 2$ receptors and uptake sites in the neocortex of the rhesus monkey. $\mathrm{J}$ Comp Neurol 280:27-42.

Lipton SA, Kater SB (1989) Neurotransmitter regulation of neuronal outgrowth, plasticity and survival. Trends Neurosci 12:265-270.

Livingstone MS, Hubel DH (1984a) Anatomy and physiology of a colour system in the primate visual cortex. J Neurosci 4:309-356.

Livingstone MS, Hubel DH (1984b) Specificity of intrinsic connections in primate primary visual cortex. J Neurosci 4:2830-2835.

Livingstone MS, Hubel DH (1987a) Connections between layer 4B of area 17 and thick cytochrome oxidase stripes of area 18 in the squirrel monkey. J Neurosci 7:3371-3377.

Livingstone MS, Hubel DH (1987b) Psychophysical evidence for separate channels for the perception of form, color, movement, and depth. J Neurosci 7:3416-3468.

Löwel S, Singer W (1987) The pattern of ocular dominance columns in flat-mounts of the cat visual cortex. Exp Brain Res 68:661-666.

Löwel S, Singer W (1992) Selection of intrinsic horizontal connections in the visual cortex by correlated activity. Science 255:209-212.

Löwel S, Freeman B, Singer W (1987) Topographic organization of the orientation column system in large flat-mounts of the cat visual cortex: a 2-deoxyglucose study. J Comp Neurol 255:401-415.

Löwel S, Bischof HJ, Leutenecker B, Singer W (1988) Topographic relations between ocular dominance and orientation columns in the cat striate cortex. Exp Brain Res 71:33-46.

Luhmann HJ, Martinez-Millan L, Singer W (1986) Development of horizontal intrinsic connections in cat striate cortex. Exp Brain Res 63:443-448.

Lyon RA, Titeler M (1988) Pharmacology and biochemistry of the 5-HT2 receptor. In: The serotonin receptors (Sanders-Bush E, ed), pp 59-88. Clifton, NJ: Humana.

Lyon RA, Davis KH, Titeler M (1987) $\left[{ }^{3} \mathrm{H}\right] \mathrm{DOB}$ labels a guanyl nucleotide-sensitive state of cortical 5-HT2 receptors. Mol Pharmacol 31:194-199.

Marcinkiewicz M, Vergé D, Gozlan H, Pichat L, Hamon M (1984) Autoradiographic evidence for the heterogeneity of 5-HT1 sites in the rat brain. Brain Res 291:159-163.

Marcusson JO, Morgan DG, Winblad B, Finch CE (1984) Serotonin-2 binding sites in human frontal cortex and hippocampus. Selective loss of S-2A sites with age. Brain Res 311:51-56.

Mattson MP (1988) Neurotransmitters in the regulation of ncuronal cytoarchitecture. Brain Res Rev 13:179-212.

McCall MA, Tong L, Spear PD (1988) Development of neuronal responses in cat posteromedial lateral suprasylvian visual cortex. Brain Res 447:67-78.

McKenna DJ, Peroutka SJ (1989) Differentiation of 5-hydroxytryptamine-2 receptor subtypes using ${ }^{125} I-R-(-) 2,5$-dimethoxy-4-iodo-phenylisopropylamine and ${ }^{3} \mathrm{H}$-ketanserin. J Neurosci 9:3482-3490.

McKenna DJ, Nazarali AJ, Hoffman AJ, Nichols DE, Mathis CA, Saavedra JM (1989) Common receptors for hallucinogens in rat brain: a comparative autoradiographic study using [125I]LSD and [125I]DOI, a new psychotomimetic radiogliand. Brain Res 476:45-56.

Mengod G, Nguyen H, Le H, Waeber C, Lubbert H, Palacios JM (1990a) The distribution and cellular localization of the scrotonin $1 \mathrm{C}$ receptor mRNA in the rodent brain examined by in situ hybridization histochemistry. Comparison with receptor binding distribution. Neuroscience 35:577-591.

Mengod G, Pompeiano M, Martínez MI, Palacios JM (1990b) Localization of the mRNA for the 5-HT2 receptor by in situ hybridization histochemistry. Correlation with the distribution of receptor sites. Brain Res 524:139-143

Middlemiss DN, Palmer AM, Edel N, Bowen DM (1986) Binding of the novel serotonin agonist 8-hydroxy-2-(di-n-propyl-amino)tetralin in normal and Alzheimer brain. J Neurochem 46:993-996.

Molineaux SM, Jessell TM, Axel R, Julius D (1989) 5-HT IC receptor is a prominent serotonin receptor subtype in the central nervous system. Proc Natl Acad Sci USA 86:6793-6797.

Molliver ME (1987) Serotonergic ncuronal systems: what their anatomic organization tells us about function. J Clin Psychopharmacol $7: 3-23$.

Morrison JH, Foote SL (1986) Noradrenergic and serotonergic innervation of cortical, thalamic, and tectal visual structures in old and new world monkeys. J Comp Neurol 243:117-138.

Morrison JH, Foote SL, Molliver ME, Bloom FE, Lidov HG (1982) Noradrenergic and serotonergic fibers innervate complementary lay- 
ers in monkey primary visual cortex: an immunohistochemical study. Proc Natl Acad Sci USA 79:2401-2405.

Morrison JH, Foote SL, Bloom FE (1984) Regional, laminar, developmental, and functional characteristics of noradrenaline and serotonin innervation patterns in monkey cortex. In: Monoamine innervation of cerebral cortex (Descarries L, Reader T, Jasper H, eds), pp 61-75. New York: Liss.

Mulligan KA, Törk I (1988) Serotoninergic innervation of the cat cerebral cortex. J Comp Neurol 270:86-110.

Murphy KM, Van Sluyters RC, Jones DG (1990) Cytochrome-oxidase activity in cat visual cortex: is it periodic? Soc Neurosci Abstr 16: 292.

Nakazawa M, Koh T, Kani K, Maeda T (1992) Transient patterns of serotonergic innervation in the rat visual cortex: normal development and effects of neonatal enucleation. Dev Brain Res 66:77-90.

Nelson DR, Thomas DR (1989) [ $\left.{ }^{3} \mathrm{H}\right]$ BRL43694 (granisetron), a specific ligand for 5-HT3 binding sites in rat brain cortical membranes. Biochem Pharmacol 38:1693-1695.

Olavarria J, Van Sluyters RC (1985) Unfolding and flattening the cortex of gyrencephalic brains. J Neurosci Methods 15:191-202.

Olson CR, Freeman RD (1980) Profile of the sensitive period for monocular deprivation in kittens. Exp Brain Res 39:17-21.

Otsuka R, Hassler R (1962) ÏTher Aufbau und Gliederung der corticalen Sehsphäre bei der Katze. Arch Psychiatr Nervenkr 203:212234.

Papadopoulos GC, Parnavelas JG, Buijs RM (1987) Light and electron microscopic immunocytochemical analysis of the serotonin innervation of the rat visual cortex. J Neurocytol 16:883-892.

Parkinson D, Coscia EC, Daw NW (1989) Identification and localization of 5-hydroxytryptamine receptor sites in macaque visual cortex. Vis Neurosci 2:515-525.

Pazos A, Palacios JM (1985) Quantitative autoradiographic mapping of serotonin receptors in the rat brain. I. Serotonin-1 receptors. Brain Res 346:205-230.

Pazos A, Hoyer D, Palacios JM (1984a) Mesulergine, a selective serotonin-2 ligand in the rat cortex, does not label these receptors in porcine and human cortex: evidence for species differences in brain serotonin-2 receptors. Eur J Pharmacol 106:531-538.

Pazos A, Hoyer D, Palacios JM (1984b) The binding of serotonergic ligands to the porcine choroid plexus: characterization of a new type of serotonin recognition site. Eur J Pharmacol 106:539-546.

Pazos A, Cortes R, Palacios JM (1985) Quantitative autoradiographic mapping of serotonin receptors in the rat brain. II. Serotonin-2 receptors. Brain Res 346:231-249.

Pazos A, Probst A, Palacios JM (1987a) Serotonin receptors in the human brain-III. Autoradiographic mapping of serotonin-1 receptors. Neuroscience 21:97-122.

Pazos A, Probst A, Palacios JM (1987b) Serotonin receptors in the human brain-IV. Autoradiographic mapping of serotonin-2 receptors. Neuroscience 21:123-139.

Pazos A, Hoyer D, Dietl MM, Palacios JM (1988) Autoradiography of serotonin receptors. In: Neuronal serotonin (Osborne NN, Hamon M, eds), pp 507-543. New York: Wiley.

Pazos A, Gonzálcz AM, Wacber C, Palacios JM (1991) Multiple serotonin receptors in the human brain. In: Receptors in the human nervous system (Mendelsohn FAO, Paxinos G, eds), pp 71-101. San Diego: Academic.

Pedigo NW, Yamamura HI, Nelson DL (1981) Discrimination of multiple $\left[{ }^{3} \mathrm{H}\right] 5$-hydrox tryptamine binding sites by the neuroleptic spiperone in rat brain. $J$ Neuroschem 36:220-226.

Peroutka SJ (1990) 5-Hydroxytryptamine receptor subtypes. Pharmacol Toxicol 67:373-383.

Peroutka SJ, Snyder SH (1979) Multiple serotonin receptors; differential binding of ${ }^{3} \mathrm{H}-5 \mathrm{HT},{ }^{3} \mathrm{H}$-LSD, and ${ }^{3} \mathrm{H}$-spiroperidol. Mol Pharmacol 16:687-695.

Pierce PA, Peroutka SJ (1989) Evidence for distinct 5-HT2 binding site subtypes in cortical membrane preparations. J Neurochem 52: 656-658.

Pompeiano M, Palacios JM, Mengod G (1992) Distribution and cellular localization of mRNA coding for 5-HT1A receptor in the rat brain: correlation with receptor binding. J Neurosci 12:440-453.

Price DJ (1986) The postnatal development of clustered intrinsic connections in area 18 of the visual cortex in kittens. Dev Brain Res 24: $1-2$.

Price DJ, Zumbroich TJ, Blakemore C (1988) Development of stim- ulus selectivity and functional organization in the suprasylvian visual cortex of the cat. Proc R Soc Lond [Biol] 233:123-163.

Prusky G, Cynader M (1990) The distribution of M-1 and M-2 muscarinic acetylcholine receptor subtypes in the developing cat visual cortex. Dev Brain Res 56:1-12.

Prusky GT, Shaw C, Cynader MS (1987) Nicotine receptors are located on lateral geniculate nucleus terminals in cat visual cortex. Brain Res 412:131-138.

Radja F, Laporte A-M, Daval G, Vergé D, Gozlan H, Hamon M (1991) Autoradiography of serotonin receptor subtypes in the central nervous system. Neurochem Int 18:1-15.

Rakic P, Goldman-Rakic PS, Gallager DW (1988) Quantitative autoradiography of major neurotransmitter receptors in striate and extrastriate cortex. J Neurosci 8:3670-3690.

Reynolds GP, Amold L, Rossor MN (1984) Reduced binding of $\left[{ }^{3} \mathrm{H}\right]$ ketanserin to cortical 5 -HT-2 receptors in senile dementia of the Alzheimer type. Neurosci Lett 44:47-51.

Richardson BP, Engel G (1986) The pharmacology and function of 5-HT-3 receptors. Trends Neurosci 9:424-428.

Roth BL, Hamblin MW, Ciaranello RD (1991a) Developmental regulation of 5HT2 and 5HT1C mRNA and receptor levels. Dev Brain Res 58:51-58.

Roth BL, Hamblin MW, Desai R, Ciaranello RD (1991b) Developmental and synaptic regulation of 5-HT2 and 5-HT1C serotonin receptors. In: Serotonin: molecular biology, receptors and functional effects (Fozard JR, Saxena PR, eds), pp 33-42. Basel: Birkhauser.

Sanders-Bush E (1988) 5-HT receptors coupled to phosphoinositide hydrolysis. In: The serotonin receptors (Sanders-Bush E, ed), pp 181198. Clifton, NJ: Humana.

Schöen SW, Leutenecker B, Kreutzberg GW, Singer W (1990) Ocular dominance plasticity and developmental changes of $5^{\prime}$-nucleotidase distributions in the kitten visual cortex. J Comp Neurol 296:379_ 392.

Shatz C, Luskin MB (1986) The relationship between the geniculocortical afferents and their cortical target cells during development of the cat's primary visual cortex. J Neurosci 6:3655-3668.

Shatz CJ, Stryker MP (1978) Ocular dominance in layer IV of the cat's visual cortex and the effects of monocular deprivation. J Physiol (Lond) 281:267-283.

Shatz CJ, Lindström S, Wiesel TN (1977) The distribution of afferents representing the right and left eyes in the cat's visual cortex. Brain Res 131:103-116.

Shaw C, Needler MC, Wilkinson M, Aoki C, Cynader M (1984) Alterations in receptor number, affinity and laminar distribution in cat visual cortex during the critical period. Neuropsychopharmacology 8:627-634.

Shaw C, Wilkinson M, Cynader M, Needler MC, Aoki C, Hall SE (1986) The laminar distributions and postnatal development of neurotransmitter and neuromodulator receptors in cat visual cortex. Brain Res Bull 16:661-671.

Sherman SM (1985) Functional organization of the W-, X-, and Y-cell pathways in the cat: a review and hypothesis. In: Progress in psychobiology and physiological psychology (Sprague JM, Epstein AN, eds), pp 233-314. New York: Academic.

Swindale NV, Matsubara JA, Cynader MS (1987) Surface organization of orientation and direction selectivity in cat area 18 . J Neurosci 7:1414-1427.

Teitler M, Leonhardt S, Weisberg EL, Hoffman BL (1990) 4-[125I]iodo(2,5-dimethoxy)phenylisopropylamine and $\left[{ }^{3} \mathrm{H}\right]$ ketanserin labeling of 5-HT2 receptors in mammalian cells transfected with a rat 5-HT2 cDNA: evidence for multiple states and not multiple 5-HT2 receptor subtypes. Mol Pharmacol 38:594-596.

Titeler M, Lyon RA, Davis KH, Glennon RA (1985) Role of $\left[{ }^{3} \mathrm{H}\right] \mathrm{DOB}$, a 5-HT2 agonist radioligand. Biochem Pharmacol 36:3265-3271.

Titeler M, Herrick K, Lyon RA, MacKenney JD, Glennon RA (1987) [ $\left.{ }^{3} \mathrm{H}\right]$ DOB: a specific agonist radioligand for 5 -HT2 receptors. Eur $J$ Pharmacol 117:145-146.

Tong LL, Kalil RE, Spcar PD (1991) Development of the projections from the dorsal lateral geniculate nucleus to the lateral suprasylvian visual area of cortex in the cat. J Comp Neurol 314:526-533.

Tusa RJ, Palmer LA (1980) Retinotopic organization of areas 20 and 21 in the cat. J Comp Neurol 193:147-164.

Tusa RJ, Palmer LA, Rosenquist AC (1978) The retinotopic organization of area 17 (striate cortex) in the cat. J Comp Neurol 177: 213-236. 
Tusa RJ, Rosenquist AC, Palmer LA (1979) Retinotopic organization of area 18 and 19 in the cat. J Comp Neurol 185:657-678.

Tusa RJ, Palmer LA, Rosenquist AC (1981) Multiple cortical visual areas: visual field topography in the cat. In: Multiple visual areas (Woolsey CN, ed), pp 1-31. New York: Humana.

Uphouse LL, Bondy SC (1981) The maturation of cortical serotonin binding sites. Dev Brain Res 1:415-417.

Uzbekov MG, Murphy S, Rose SPR (1979) Ontogenesis of serotonin "receptors" in different regions of rat brain. Brain Res 168:195-199.

Van Essen DC, Maunsell JHR (1980) Two-dimensional maps of the cerebral cortex. J Comp Neurol 191:255-281.

Voigt T, De Lima AD (1991a) Serotoninergic innervation of the ferret cerebral cortex. I. Adult pattern. J Comp Neurol 314:403-414.

Voigt T, De Lima AD (1991b) Serotoninergic innervation of the ferret cerebral cortex. II. Postnatal development. J Comp Neurol 314:415428.

Waeber C, Hoyer D, Palacios JM (1989) 5-Hydroxytryptamine 3 receptors in the human brain: autoradiographic visualization using ${ }^{3} \mathrm{H}$ ICS 205-930. Neuroscience 31:393-400.

Whitaker-Azmitia PM (1991) Role of serotonin and other neurotransmitter receptors in brain development: basis for developmental pharmacology. Pharmacol Rev 43:553-561.
Wong DF, Wagner HN, Dannals RF, Links JM, Frost JJ, Ravert HT, Wilson AA, Kuhar MJ (1984) Effects of age on dopamine and serotonin receptors measured by positron tomography in the living human brain. Science 226:1393-1396.

Wong-Riley M (1979) Changes in the visual system of monocularly sutured or enucleated cats demonstrable with cytochrome oxidase histochemistry. Brain Res 171:11-28.

Yagaloff KA, Hartig PR (1985) ${ }^{125}$ I-lysergic acid diethylamide binds to a novel serotonergic site on rat choroid plexus epithelial cells. J Neurosci 5:3178-3183.

Zifa E, Fillion G (1992) 5-Hydroxytryptamine receptors. Pharmacol Rev 44:401-458.

Zifa E, Hernandez J, Fayolle C, Fillion G (1988) Postnatal development of 5-HT1 receptors: $\left[{ }^{3} \mathrm{H}\right] 5$-HT binding sites and 5-HT induced adenylate cyclase activations in rat brain cortex. Dev Brain Res 44: 133-140.

Zilles K, Schleicher A, Glaser T, Traber J, Rath M (1985) The ontogenetic development of serotonin (5-HTl) receptors in various cortical regions of the rat brain. Anat Embryol (Berl) 172:255-264.

Zilles K, Rath M, Schleicher A (1986) Ontogenesis of serotonin (5HT) binding sites in the choroid plexus of the rat brain. Brain Res 380:201-203. 